DOI: 10.12731/2070-7568-2020-4-166-206 УДК 332.144

\title{
ВЫЯВЛЕНИЕ ТИПОВЫХ ПРОФИЛЕЙ РЕГИОНОВ С ТЕНДЕНЦИЕЙ К РОСТУ СОЦИАЛЬНОЙ НАПРЯЖЕННОСТИ НА ОСНОВЕ АНАЛИЗА ДАННЫХ СТАТИСТИКИ СУБЬЕКТОВ ФЕДЕРАЦИИ (ПЕРВОЕ ПОЛУГОДИЕ 2020 Г.)
}

\section{Кузина Н.В.}

В настоящее время все более актуальньли в связи с разворачивающимся экономическим и сочиальнымм кризисом становятся методики прогнозирования сощиальной и этно-культурной напряженности в регионах Российской Федерации с изелью своевременного применения мер профилактики и предупреждения сочиальньх взрывов.

Цель - прогнозирование зон сочиальной напряженности и возможных локальных сочииальных взрывов на основании имеющихся статистических данных об экономической и сочиальной жизни регионов; выявление факторов-индикаторов возможного сочиильного взрыва; описание основных профилей регионов с высоким уровнем риска роста социиальной напряженности.

Методика исследования. Проанализировань 70 показателей экономической, финансовой, демографической, соииальной ситуации в регионах Российской Федеращии за первое полугодие 2020 г. (январь-июнь, январь-июль) с иелью выявления наиболее уязвимых регионов (данные ГУ МВД, Генеральной Прокуратуры России, Росстата, Минобрнауки России, Минздрава России). Данные были обработаны с помощью непараметрических методов математической статистики (коррелячиионный анализ, пакет STATISTICA 13).

Результаты. Выявлены два основных профиля регионов с тенденцичей к росту соччиальной напряженности.

Область применения результатов. Выводы исследования будут полезны для органов государственного управления федерального и регионального уровней, для политических партий, крупных консалтинговых, логистических и страховых компаний, федеральных ритейлеров. 
Ключевые слова: экономическая политика; сочиальная политика; безопасность; пандемия; регионоведение; сочиильная напряженность.

\section{IDENTIFICATION OF TYPICAL PROFILES OF REGIONS WITH A TENDENCY TO GROWTH IN SOCIAL TENSION BASED ON ANALYSIS OF STATISTICS DATA OF FEDERATION SUBJECTS (FIRST HALF 2020)}

\section{Kuzina N.V.}

Currently, in connection with the unfolding economic and social crisis, methods of forecasting social and ethno-cultural tensions in the regions of the Russian Federation are becoming more and more relevant in order to timely prevent and prevent social explosions.

Purpose - forecasting zones of social tension and possible local social explosions on the basis of available statistical data on the economic and social life of the regions; identification of factors-indicators of a possible social explosion; description of the main profiles of regions with a high level of risk of increasing social tension.

Research methodology. We analyzed 70 indicators of the economic, financial, demographic, social situation in the regions of the Russian Federation in the first half of 2020 (January-June, January-July) in order to identify the most vulnerable regions (data from the Main Directorate of the Ministry of Internal Affairs, the General Prosecutor's Office of Russia, Federal Service statistics of Russia, the Ministry of Education and Science of Russia, Ministry of Health of Russia). The data were processed using nonparametric methods of mathematical statistics (correlation analysis, STATISTICA 13 package).

Results. Two main profiles of regions with a tendency to an increase in social tension were identified.

Practical implications. The findings of the study will be useful for government bodies at the federal and regional levels, for political parties, large consulting, logistics and insurance companies, federal retailers.

Keywords: economic policy; social policy; safety; pandemic; regional studies; social tension. 
Изучение социальной напряженности современной западной и отечественной наукой в исторической перспективе базируется на основополагающих открытиях, сделанных в рамках марксистско-ленинской теории и связанных прежде всего с раскрытыми механизмами смены общественно-экономических формаций, в том числе через социальный взрыв. По сравнению с политическими и экономическими трудами 150-летней давности современная наука выработала более разнообразный инструментарий обнаружения и исследования нарастания процесса социальной напряженности [1-5]. Существенный вклад в прогнозирование социальной напряженности в регионах вносит мониторинг динамики экономических и демографических региональных показателей, выполняемый в НИУ ВШЭ [17, 18, 21-23], в том числе-многолетние исследования Н.В. Зубаревич [6-14, 24-31].

Проблема социальной напряженности, предваряющей этап открытого социального взрыва, может быть изучена, как это сложилось в современной междисциплинарной науке, с помощью ряда приемов и подходов, распределенных по двум направлениям: 1) изучение умонастроений и комплексов идей с помощью социологических опросов (заведомо не точный и неверифицируемый путь, постепенно заменяемый методиками изучения настроений населения с помощью искусственного интеллекта - анализом содержания контента социальных сетей, полученного посредством парсинга), 2) изучение разнородных показателей официальной статистики, отражающей имеющиеся социально-экономические условия. Мы приводим только работы последних лет, выполненные в одном из данных ключей.

Достоверность данных методов не равнозначна, зависит в том числе и от полноты учета имеющихся статистических показателей. Методика анализа социальной напряженности на основе статистических данных описана, например, в исследовании И.Н. Грызлова [5]. В данной работе индекс социального потенциала и индекс протестной активности региона выявляет по результатам анализа статистических данных. 
Говоря о неудовлетворенности уровнем жизни населения в регионах как об источнике социальной напряженности, приведем некоторые основополагающие наблюдения из работы 2019 г. Н.В. Зубаревич, С.Г. Сафронова, суммирующей данные более, чем за 15 лет: «Доходы, уровень бедности, структура потребления и финансовое поведение населения за постсоветский период исследованы экономической наукой $<\ldots>$ Региональный ракурс этих изменений остается на периферии внимания экономистов и слабо изучен в географической науке. Мы плохо представляем, насколько велики региональные различия в широком контексте «люди и деньги», насколько региональные тенденции схожи с общероссийскими или отличаются от них. Наименее изучены 2010-е годы, когда реальные денежные доходы населения достигли максимума, а затем произошел длительный спад в период последнего кризиса (на 11\% за 2014-2018 гг.)» [15]. Мы можем предположить, что субъективная неудовлетворенность населения уровнем жизни будет зависеть от данных различий. Причем в высокоразвитых регионах можно предположить наличие неудовлетворенности степенью субъективно понимаемой «свободы волеизъявления», а в депрессивных регионах - наличие неудовлетворенности материальным уровнем жизни. Чтобы прогнозирование и профилактика социальной напряженности были эффективными, необходим методологически и методически выверенный алгоритм расчетов комплексных показателей, указывающих на рейтинг региона - как в части экономики, так и в сфере эффективности социальной политики. При этом, «самая трудная задача - с помощью математических методов оценить влияние возрастной структуры населения регионов, уровня доходов и бедности на структуру расходов и характеристики финансового поведения, а также роль доходных факторов в периоды экономического роста и кризисов. Трудности обусловлены проблемами достоверности региональной статистики доходов и бедности, существенными различиями только «по краям» при схожести большинства регионов; неконсистентностью части измеряемых параметров» [15]. В анализируемом многолетнем исследовании авторов использовался метод парных корреляций «груп- 
пировок регионов с разными значениями на несколько дат», множественный регрессионный анализ с целью установления «степени влияния демографических и социально-экономических факторов на разные аспекты поведения населения в потребительской и финансовой сфере в течение 2000-х годов» [15]. Исследователи выделяют в итоге три основные группы факторов, влияющих на уровень бедности населения региона: расселение (плотность населения), разница в доходах групп населения и стоимость жизни в регионе, отношение доходов к величине прожиточного минимума региона [15]. В целом, региональное неравенство в доходах в Российской Федерации чрезвычайно значительно и составляло разницу в 15,3 раз в 2017 г. Доходы населения различаются «от 18 раз в развитых регионах до 8-9 раз в средне- и менее развитых регионах» [15]. Косвенно негативный прогноз в области социальной напряженности дает наблюдение о том, что население региона не может позволить себе воспользоваться платными услугами в области образования и здравоохранения [15]. Доля расходов на услуги отдыха и культуры в таких регионах также остается низкой и не изменяется [15].

Кредитная задолженность населения также является одним из наиболее важных показателей высокой социальной напряженности в регионе. По наблюдениям исследователей, в последние годы «максимальную кредитную нагрузку относительно доходов имели жители богатых нефтегазодобывающих регионов», а также Урал, Сибирь и Северо-Запад, некоторые автономные республики [15], при этом «в большинстве регионов просроченная задолженность по всем кредитам в 2018 г. составляла от 3 до 6\%», однако в Северо-Кавказских республиках она была существенно выше [15]. Просроченная задолженность по ипотеке была характерна для Москвы, Северного Кавказа, некоторых сибирских регионов (Алтай, Бурятия, Тыва, Красноярский край) [15]. В современных условиях к привычным индикаторам социальной напряженности прибавляются и связанные с новыми трудовыми практиками или с вводимыми форсмажорными мерами, в частности - с вынужденной дистанционной формой работы во время пандемии COVID-19 [16]. 
Цель исследования - прогнозирование зон социальной напряженности и локальных социальных взрывов, вероятности протестной активности на основании имеющихся статистических данных об экономической и социальной жизни регионов; определение условных профилей регионов с наибольшей угрозой социального взрыва на основании анализа открытых статистических данных министерств и ведомств; выявление социально-экономических индикаторов возможного взрыва. Цель выявить влияние антикоронавирусных мер на социальную стабильность в данном исследовании не ставилась. Выявление универсальных профилей регионов с тенденцией к росту социальной напряженности даст возможность затем прогнозировать её угрозы, устанавливая меру близости профиля к показателям конкретного субъекта Федерации.

\section{Материал исследования}

Проанализированы 70 показателей экономической, финансовой, демографической, социальной ситуации в регионах Российской Федерации за первое полугодие 2020 г. (январь-июнь, январь-июль 2020 г.), а именно - учитывались: всё население региона, городское и сельское население региона, количество родившихся и умерших (январь-июнь 2020), умерших от COVID-19 (май 2020 г.), умерших от COVID-19 (июнь 2020 г.), количество заключенных браков и разводов (январь-июнь 2020 г.), среднегодовой доход домохозяйств, средняя задолженность домохозяйств и средний депозит домохозяйств (2-й квартал 2020 г.), внешняя миграция - количество фактов постановки на миграционный учет, количество случаев первично оформленного миграционного учета, оформленных разрешений на работу от внешних мигрантов, снятий с миграционного учета, принятых решений о выдаче разрешений на временное проживание, количество имеющих у внешних трудовых мигрантов разрешений на временное проживание на конец периода, количество решений о выдаче внешним мигрантам вида на жительство, действительных видов на жительство у внешних мигрантов на конец периода, принятых решений о выдаче гражданства Российской 
Федерации (январь-июнь 2020 г.), имеющиеся у работодателей вакансии (1-й квартал 2020 г.), вакансии у работодателей за полугодие - январь-июнь 2020 г., количество рабочей силы 15-72 лет за полугодие, работающих трудоспособного возраста (15-72 лет), безработных трудоспособного возраста (15-72 лет, январь-июнь 2020 г.), неработающих пенсионеров, всего пенсионеров (на начало 2020 г.), количество рабочей силы (май-июль 2020 г.), занятых трудоспособного возраста (май-июль 2020 г.), безработных трудоспособного возраста (май-июль 2020 г.), прожиточный минимум, начисленная заработная плата (І-е полугодие 2020 г.), начисленная заработная плата работников организаций, среднемесячный доход на душу населения, потребительские среднемесячные расходы на душу населения (I-е полугодие 2020 г.), средняя заработная плата (май 2020 г.), оборот пищевых продуктов (январь-июнь 2020 г.), стоимость минимального набора товаров и услуг для сравнения покупательской способности в регионах (июнь 2020 г.), расходы на потребление на одного члена семьи, в том числе расходы на питание, оплату ЖКХ, транспорт, отдых, образование (в процентах от общей суммы расходов на потребление на одного члена семьи), количество врачей в регионе, из них - врачей в сельской местности, количество койко-мест и больничных учреждений в регионе, количество самостоятельных организаций высшего образования, количество выпускников высших учебных заведений, валовая добавленная стоимость по региону, расходы на социальную поддержку в регионе в 2019 г. и на июнь 2020 г., поступления в бюджет от субъекта федерации (І-е полугодие 2020 г.), поступления в федеральный бюджет от региона, поступления в бюджет субъекта Федерации от региона, задолженность региона по налогам общая, задолженность региона по федеральным налогам, задолженность региона по региональным налогам, доходы консолидированного бюджета региона, расходы консолидированного бюджета региона, профицит/дефицит консолидированного бюджета региона (I-е полугодие 2020 г.), количество преступлений (январь-июль 2020 г.), количество преступлений террористического характера, количество 
преступлений экстремистского характера, количество преступлений в отношении иностранных граждан и лиц без гражданства, количество совершенных иностранными гражданами и лицами без гражданства преступлений (январь-июль 2020 г.), количество домохозяйств с выходом в Интернет и др. Использовались официально опубликованные открытые данные, предлагаемые ГУ МВД [19], Генеральной Прокуратурой России [20], Росстатом [15], Минобрнауки России, Минздравом России.

Нами не рассматривались предварительные специальные данные Минздрава России за 2020 г., вызывающие дискуссии в связи с используемыми методами их учета, а именно: изменения в финансировании системы здравоохранения по регионам, количество размещенных временных дополнительных койко-мест, заболеваемость COVID-19 по данным тестирования и компьютерной томографии. Из специфических явлений, характеризующих демографические и социально-экономические процессы в период пандемии COVID-19, рассматривались показатели общей за полгода смертности и специальные (в связи с диагнозом) показатели смертности (май, июнь 2020 г.), изменения в сфере внешней миграции, занятости, средней и начисленной заработной платы, доходов и расходов консолидированного бюджета, а также отчислений в региональный и федеральный бюджет, динамику соцподдержки населения, расходов домохозяйств и т.п. Было принципиально важным подобрать и учесть показатели, характеризующие как период COVID-19, так и «мирное» время с целью последующего сравнения различных хронологических периодов.

\section{Методика исследования}

Данные обрабатывались с помощью корреляционного анализа (коэффициент Спирмена, p), пакет STATISTICA 13. На основании выделенных корреляций описывались гипотетические профили регионов, где наблюдается рост социальной напряженности и при определенных условиях (в частности, при наличии акторов, мобилизующих население) возможен социальный взрыв. 


\section{Результаты исследования и их обсуждение}

Были выявлены два основных профиля регионов с тенденцией к росту социальной напряженности в нескольких разновидностях. Важнейшими показателями стали закредитованность населения, затраты на питание по отношению к общему доходу домохозяйства, а также количество безработных, величина потока внешних трудовых мигрантов, объем доходов и расходов консолидированного бюджета, количество экстремистских и других преступлений в регионе. Продемонстрируем взаимосвязь показателя «средняя задолженность домохозяйства» с остальными показателями. Приведем коэффициент Спирмена (p), значения которого свидетельствуют о значимой взаимозависимости показателей, преимущественно сильной положительной $(1-0,70)$, умеренной положительной $(0,69-0,30)$, слабой положительной или умеренной отрицательной $(-0,69--0,30)$, слабой отрицательной корреляции (данные в таблицах расположены по убыванию). Здесь и далее сильную корреляционную связь (как положительную, так и отрицательную) будем выделять в таблице полужирным шрифтом, умеренную (как положительную, так и отрицательную) - курсивом (Таблица 1).

Таблицуа 1.

Корреляция показателя «средняя задолженность домохозяйства (2-й квартал 2020 г.) и иных факторов (коэффициент Спирмена, p, при р<0,05) по убыванию

\begin{tabular}{|l|c|}
\hline \multicolumn{1}{|c|}{ Взаимозависимые факторы по 85-ти регионам } & $\begin{array}{c}\text { Средняя задол- } \\
\text { женность домо- } \\
\text { хозяйства (2020, } \\
\text { II кв), руб. }\end{array}$ \\
\hline Средняя заработная плата, 2020, май, руб. & $\mathbf{0 , 8 5}$ \\
\hline $\begin{array}{l}\text { Начисленная заработная плата работников организаций, I } \\
\text { п/г 2020, руб. }\end{array}$ & $\mathbf{0 , 8 2}$ \\
\hline Среднемесячный доход на душу насел., I п/г 2020, руб. & 0,66 \\
\hline Потребление на одного члена семьи, I кв. 2020, руб. & 0,64 \\
\hline Средний депозит домохозяйства (2920, II кв.), руб. & 0,62 \\
\hline $\begin{array}{l}\text { Потребительские среднемесячные расходы на душу } \\
\text { населения, І п/г 2020, руб. }\end{array}$ & 0,60 \\
\hline $\begin{array}{l}\text { Минимальный набор товаров и услуг для сравнения } \\
\text { покупательской способности в регионах, июнь 2020, руб. }\end{array}$ & 0,56 \\
\hline
\end{tabular}


Окончание табл. 1.

\begin{tabular}{|l|c|}
\hline Прожиточный минимум в регионе, 2019, руб. & 0,55 \\
\hline Среднегодовой доход домохозяйства, руб. (2020, II кв.). & 0,55 \\
\hline Поступило в бюджет субъекта, І п/г 2020, тыс. руб. & 0,48 \\
\hline Поступило от субъекта, І п/г 2020, тыс. руб. & 0,44 \\
\hline $\begin{array}{l}\text { ВРП (валовая добавленная стоимость) региона за 2018 г., } \\
\text { тыс. руб. }\end{array}$ & 0,43 \\
\hline $\begin{array}{l}\text { Консолидированный бюджет региона, доходы, I п/г 2020, } \\
\text { тыс. руб. }\end{array}$ & 0,42 \\
\hline Расходы - соцподдержка в регионе на 06.2020, тыс. руб. & 0,41 \\
\hline Расходы - соцподдержка в регионе на 12.2019, тыс. руб. & 0,41 \\
\hline Консолидированный бюджет, расходы, I п/г 2020, тыс. руб. & 0,41 \\
\hline Расходы домохозяйства (І кв. 2020), транспорт, \% & 0,40 \\
\hline Мигранты с целью работы внешние (01.20-06.20), чел. & 0,38 \\
\hline $\begin{array}{l}\text { Количество фактов снятия с миграционного учета } \\
\text { (01.20-06.20), чел. }\end{array}$ & 0,37 \\
\hline $\begin{array}{l}\text { Поступило в федеральный бюджет от субъекта, І п/г 2020, } \\
\text { тыс. руб. }\end{array}$ & 0,37 \\
\hline Расходы домохозяйства (І кв. 2020), отдых, \% & 0,36 \\
\hline $\begin{array}{l}\text { Количество фактов постановки на миграционный учет } \\
\text { (01.20-06.20), чел. }\end{array}$ & 0,34 \\
\hline Задолженность региона по федеральным налогам, І п/г, \\
2020, тыс.руб. & 0,32 \\
\hline Доля домохозяйств с выходом в Интернет (\%), 2019 г. & 0,32 \\
\hline $\begin{array}{l}\text { Первично оформленный миграционный учет } \\
\text { (01.20-06.20), чел. }\end{array}$ & 0,32 \\
\hline Требуемые работники - І кв. 2020, тыс. чел. & 0,31 \\
\hline $\begin{array}{l}\text { Преступлений в отношении иностранных граждан } \\
\text { и лиц без гражданства (01.20-07.20) }\end{array}$ & $-0,21$ \\
\hline $\begin{array}{l}\text { Вакантные места по данным службы занятости, конец } \\
\text { 06.2020, чел. }\end{array}$ & $-0,52$ \\
\hline Задолженность региона по налогам, всего, І п/г 2020, тыс. руб. \\
\hline Умерших с диагнозом СОУІD-19 за 05.2020, чел. \\
\hline Расходы домохозяйств (І кв. 2020), питание, \% \\
\hline
\end{tabular}

Согласно полученным данным, высокая закредитованность свойственна для регионов с высокой заработной платой, высокими доходами домохозяйств, с активными мерами соцподдержки, большим количеством вакантных рабочих мест, низкой смертностью и низкими расходами домохозяйств на питание, но повышенными - 
на транспорт и отдых. Данные регионы привлекают мигрантов, при этом характеризуются высоким уровнем преступности по отношению к ним. Можно предположить, что имеющиеся кредиты население данных регионов тратит в эпоху начавшегося кризиса не на товары первой необходимости, а на поддержание высокого уровня потребления, в том числе на отдых. В подобных регионах, профиль которых дан выше (условно-независимых от центра, регионах-донорах) может наблюдаться рост напряженности. Однако без использования полит-технологий или наличия высокоорганизованных протестных сообществ неудовлетворенность населения не перейдет в протест: сдерживающим фактором будет выступать страх потери работы и утраты возможностей своевременно реализовывать взятые на себя финансовые обязательства. Таким образом, в данных регионах необходим мониторинг протестной повестки, настроений граждан, наличия и активности лидеров протеста. Назовем данный профиль 1 а.

Другой тип регионов характеризуется высокими расходами домохозяйств на продукты питания, это беднейшие дотационные регионы. Назовем данный профиль 2 а. Приведем сведения о корреляции показателя «расходы на питание» с иными факторами (Таблица 2).

Таблица 2.

Корреляция показателя «расходы на питание (I кв. 2020, \%) и иных факторов (коэффициент Спирмена, $p$, при р <0,05) по убыванию

\begin{tabular}{|l|c|}
\hline \multicolumn{1}{|c|}{ Взаимозависимые факторы по 85-ти регионам } & $\begin{array}{c}\text { Расходы до- } \\
\text { мохозяйств } \\
(1 \text { кв. 2020), } \\
\text { питание\% }\end{array}$ \\
\hline $\begin{array}{l}\text { Профицит/дефицит (-), консолидированного бюджета, I п/г 2020, } \\
\text { тыс. руб. }\end{array}$ & 0,33 \\
\hline Разводов, 01.-06.2020. & $-0,22$ \\
\hline Поступило в федеральный бюджет от субъекта I п/г 2020, тыс. руб. & $-0,23$ \\
\hline $\begin{array}{l}\text { Задолженность региона по федеральным налогам, I п/г, } \\
\text { 2020, тыс. руб. }\end{array}$ & $-0,24$ \\
\hline Первично оформленный миграционный учет (01.20-06.20), чел. & $-0,24$ \\
\hline Оборот пищевых продуктов, январь-июнь, 2020, млн. руб. & $-0,26$ \\
\hline
\end{tabular}


Окончание табл. 2.

\begin{tabular}{|l|c|}
\hline Кол-во преступлений, 01.-07.2020 (01.20-07.20) & $-0,28$ \\
\hline Мигрантов с целью работы, внешних (01.20-06.20), чел. & $-0,30$ \\
\hline $\begin{array}{l}\text { Количество фактов постановки на миграционный учет } \\
(01.20-06.20), \text { чел. }\end{array}$ & $-0,30$ \\
\hline $\begin{array}{l}\text { Преступлений в отношении иностранных граждан и лиц без } \\
\text { гражданства на 07.2020 г. (01.20-07.20) }\end{array}$ & $-0,30$ \\
\hline Количество фактов снятия с миграционного учета (01.20-06.20), чел. & $-0,31$ \\
\hline Вакантные места по данным службы занятости, конец 06.2020, чел. & $-0,33$ \\
\hline Поступило от субъекта, І п/г 2020, тыс. руб. & $-0,33$ \\
\hline Консолидированный бюджет, доходы, І п/г 2020, тыс. руб. & $-0,34$ \\
\hline Требуемых работников, І кв. 2020, тыс. чел. & $-0,34$ \\
\hline Среднегодовой доход домохозяйства, руб. (2020, ІІ кв.). & $-0,35$ \\
\hline Консолидированный бюджет, расходы, І п/г 2020, тыс. руб. & $-0,35$ \\
\hline ВРП (валовая добавленная стоимость) региона за 2018,тыс.руб. & $-0,38$ \\
\hline Расходы соцподдержка в регионе на 06.2020 г., тыс. руб. & $-0,42$ \\
\hline Расходы соцподдержка в регионе на 12.2019 г., тыс. руб. & $-0,42$ \\
\hline Поступило в бюджет субъекта, І п/г 2020, тыс. руб. & $-0,42$ \\
\hline Прожиточный минимум 2019, руб. & $-0,42$ \\
\hline $\begin{array}{l}\text { Минимальный набор товаров и услуг для сравнения покупатель- } \\
\text { ной способности, июнь 2020, руб. }\end{array}$ & $-0,45$ \\
\hline Средний депозит домохозяйства (2920, II кв.), руб. & $-0,50$ \\
\hline Средняя задолженность домохозяйства (2020, II кв.), руб. & $-0,52$ \\
\hline Среднемесячный доход на душу насел., I п/г 2020, руб. & $-0,55$ \\
\hline Потребит. среднемесячные расходы на душу насел., І п/г 2020, руб. & $-0,57$ \\
\hline Расходы домохозяйств, І кв. 2020, транспорт, \% & $-0,57$ \\
\hline Средняя заработная плата, 2020, май, руб. & $-0,61$ \\
\hline Начисленная заработная плата работников организаций, І п/г & $-0,62$ \\
\hline Р020, руб. & $-0,63$ \\
\hline Расходы домохозяйств, І кв. 2020, отдых, \% & $-\mathbf{0 , 7 5}$ \\
\hline Потребление на одного члена семьи, І кв. 2020, руб. & \\
\hline
\end{tabular}

Налицо слабая и умеренная отрицательная корреляция фактора с большинством перечисленных в таблице показателей. Чем выше расходы на питание в регионе, тем меньше поступлений в бюджеты от региона, тем ниже доходы и расходы консолидированного бюджета, ниже расходы на социальную поддержку, меньше поток внешних трудовых мигрантов, ниже доходы и расходы на душу населения и в целом расходы на потребление на одного члена семьи, ниже коли- 
чество вакантных рабочих мест и ниже денежное вознаграждение работающих. Регионы с подобным профилем также будут являться неблагополучными по уровню социальной напряженности, однако также в социальный взрыв она может перерасти только в случае наличия консолидирующего центра и финансирования протеста, так как в подобных тяжелых условиях население не сможет проявлять протестную активность в силу отсутствия средств и опасений потерять минимальную стабильность.

Особый показатель, указывающий на регионы с угрозой формирования протестных настроений, - безработица. В настоящее время, судя по полученным данным о корреляции показателей, в регионах формируется явление «протестной безработицы». Она складывается в регионах с низкой заработной платой, высокой потребностью в рабочей силе (большое число вакантных рабочих мест) при хорошо развитой социальной сфере (государственное медицинское обслуживание, образование, низкая оплата за ЖКХ): население отказывается работать за низкое вознаграждение или уходит в «серую» зону. Данные регионы характеризуются высокой демографической нагрузкой (большим количеством пенсионеров и учащихся), высокой преступностью, а также высоким притоком внешних трудовым мигрантов (при высокой безработице среди автохтонного населения и большом количестве вакантных рабочих мест). Можно говорить о том, что вакантные рабочие места не востребованы местным населением, возможно - в силу низкого вознаграждения или низкого авторитета данных видов труда в глазах социума, однако наличие противоречия «высокое число безработных VS. высокое число внешних трудовых мигрантов» в данных регионах ведет к росту этно-социальной напряженности. Кроме того, люмпенизированное население с большей вероятностью будет подвержено распространению протестных настроений (особенно в случае наличия консолидирующего актора-центра или финансирования протеста). Данный тип профиля региона с высокой протестной безработицей будет близок к профилю регионов с высокими расходами домохозяйств на питание, назовем его 2 б. (Таблица 3). 
Таблицуа 3.

Корреляция показателя «безработные трудоспособного возраста (январь-июнь 2020 г.)» и иных факторов (коэффициент Спирмена, p, при р <0,05) по убыванию

\begin{tabular}{|c|c|}
\hline Взаимозависимые факторы по 85-ти регионам & $\begin{array}{c}\text { Безработных } \\
\text { трудоспо- } \\
\text { собного воз- } \\
\text { раста (15-72 } \\
\text { лет), тыс.чел. } \\
\text { (январь-июнь } \\
2020 \text { г.) }\end{array}$ \\
\hline Безработные, т.ч., май -июль & $\mathbf{1 , 0 0}$ \\
\hline Родившихся 01.-06.2020, чел. & $\mathbf{0 , 9 0}$ \\
\hline Врачей на начало 2019 & $\mathbf{0 , 8 6}$ \\
\hline Кол-во рабочей силы, тыс.чел. (15-72 лет, 01-06.20) & $\mathbf{0 , 8 5}$ \\
\hline Кол-во рабочей силы, тыс.чел., май-июль 2020 & $\mathbf{0 , 8 5}$ \\
\hline число койко-мест, на нач.2019 & $\mathbf{0 , 8 4}$ \\
\hline Браков, 01.-06.2020. & $\mathbf{0 , 8 4}$ \\
\hline Неработающих пенсионеров на 1.01.20, тыс.чел. & $\mathbf{0 , 8 3}$ \\
\hline $\begin{array}{l}\text { Работающих трудоспособного возраста 15-72 лет, тыс.чел. } \\
(01 .-06.20)\end{array}$ & $\mathbf{0 , 8 3}$ \\
\hline Занятых, тыс.чел., май-июль 2020 & $\mathbf{0 , 8 3}$ \\
\hline Кол-во студентов в организациях высшего образования, чел., 2019 & $\mathbf{0 , 8 2}$ \\
\hline Всего пенсионеров, 01.2020 г., тыс.чел. & $\mathbf{0 , 8 2}$ \\
\hline Выпущено из организаций высшего образования, чел., 2019 & $\mathbf{0 , 8 1}$ \\
\hline $\begin{array}{l}\text { Число самостоятельных организаций высшего образования, } \\
2019\end{array}$ & $\mathbf{0 , 8 0}$ \\
\hline Больничных учреждений на конец 2019 & $\mathbf{0 , 8 0}$ \\
\hline $\begin{array}{l}\text { Задолженность региона по региональным налогам, I п/г, 2020, } \\
\text { тыс.руб. }\end{array}$ & 0,78 \\
\hline Оборот пищевых продуктов, январь-июнь, 2020, млн. руб. & $\mathbf{0 , 7 7}$ \\
\hline Умерших 01.-06.2020, чел. & 0,77 \\
\hline Задолженность региона по налогам, всего, I п/г 2020, тыс. руб. & $\mathbf{0 , 7 6}$ \\
\hline Кол-во преступлений, 01.-07.2020 (01.20-07.20) & 0,76 \\
\hline Разводов 01.-06.2020. & $\mathbf{0 , 7 4}$ \\
\hline Врачей в сельской местности, на начало 2019 & $\mathbf{0 , 7 2}$ \\
\hline $\begin{array}{l}\text { Задолженность региона по федеральным налогам, I п/г, 2020, } \\
\text { тыс.руб. }\end{array}$ & $\mathbf{0 , 7 0}$ \\
\hline Консолидированный бюджет - расходы, I п/г 2020, тыс. руб. & 0,69 \\
\hline Консолидированный бюджет - доходы, I п/г 2020, тыс. руб. & 0,66 \\
\hline Число имеющих РВП на конец периода (01.20-06.20), чел. & 0,65 \\
\hline
\end{tabular}


Окончание табл. 3.

\begin{tabular}{|l|c|}
\hline Число действительные ВЖ на конец периода (01.20-06.20), чел. & 0,64 \\
\hline Преступлений террористических на 07.2020 (01.20-07.20) & 0,63 \\
\hline ВРП (валовая добавленная стоимость) региона за 2018, тыс.руб. & 0,62 \\
\hline $\begin{array}{l}\text { Вакантные места по данным службы занятости, конец 06.2020, } \\
\text { чел. }\end{array}$ & 0,62 \\
\hline Требуемых работников, І кв. 2020, тыс. чел. & 0,62 \\
\hline $\begin{array}{l}\text { Принято решений о выдаче вида на жительство (первично) } \\
01.20-06.20, \text { чел. }\end{array}$ & 0,62 \\
\hline Расходы - соцподдержка в регионе на 12.2019 г.,тыс.руб. & 0,61 \\
\hline Первично оформленный миграционный учет (01.20-06.20), чел. & 0,61 \\
\hline Расходы соцподдержка в регионе на 06.2020 г.. тыс.руб. & 0,60 \\
\hline $\begin{array}{l}\text { Преступлений в отношении иностранных граждан и лиц без } \\
\text { гражданства на 07.2020 г. (01.20-07.20) }\end{array}$ & 0,59 \\
\hline $\begin{array}{l}\text { Зарегистрировано преступлений, совершенных иностранными } \\
\text { гражданами и лицами б/г на 07.2020 (01.20-07.20) }\end{array}$ & 0,57 \\
\hline Мигранты с целью работы внешние (01.20-06.20), чел. & 0,55 \\
\hline
\end{tabular}

Показателем относительного благополучия региона в социальной и экономической сфере в Российской Федерации является величина потока внешних трудовых мигрантов. Мигранты выбирают регионы с адекватными налоговыми поступлениями в федеральный и региональный бюджет, с высокими доходами и расходами консолидированного бюджета, с большим количеством вакантных рабочих мест и высоким вознаграждением за труд, с хорошо развитыми мерами социальной поддержки, высокой брачной и репродуктивной активностью, но и высокой смертностью автохтонного населения (в том числе от COVID-19). Однако вслед за внешней миграцией в данных регионах растет количество преступлений, в том числе прежде всего в отношении иностранных граждан и лиц без гражданства, а также совершенных иностранными гражданами, террористических и экстремистских преступлений. Таким образом, регионы с подобным профилем также будут зонами риска роста этно-социальной напряженности. Они будут близки к относительно благополучным регионам с высокой закредитованностью домохозяйств, назовем данный профиль региона с высоким числом внешних трудовых мигрантов 1 б. (Таблица 4). 
Таблицуа 4.

\section{Корреляция показателя «количество внешних трудовых мигрантов (январь-июнь 2020 г.)» и иных факторов (коэффициент Спирмена, p, при р<0,05) по убыванию}

\begin{tabular}{|c|c|}
\hline Взаимозависимые факторы по 85-ти регионам & $\begin{array}{c}\text { Мигранты с } \\
\text { целью рабо- } \\
\text { ты внешние } \\
(01.20-06.20), \\
\text { чел. }\end{array}$ \\
\hline $\begin{array}{l}\text { Преступлений в отношении иностранных граждан и лиц без } \\
\text { гражданства на 07.2020 г. (01.20-07.20) }\end{array}$ & $\mathbf{0 , 8 9}$ \\
\hline Поступило в бюджет субъекта, I п/г 2020, тыс. руб. & $\mathbf{0 , 8 8}$ \\
\hline Требуемых работников, I кв. 2020, тыс. чел. & $\mathbf{0 , 8 7}$ \\
\hline ВРП (валовая добавленная стоимость) региона за 2018, тыс. руб. & $\mathbf{0 , 8 5}$ \\
\hline Консолидированный бюджет, доходы, I п/г 2020, тыс. руб. & $\mathbf{0 , 8 3}$ \\
\hline Консолидированный бюджет расходы, I п/г 2020, тыс. руб. & $\mathbf{0 , 8 2}$ \\
\hline Оборот пищевых продуктов, январь-июнь, 2020, млн. руб. & $\mathbf{0 , 8 1}$ \\
\hline Расходы - соцподдержка в регионе на 12.2019 г., тыс.руб. & $\mathbf{0 , 8 1}$ \\
\hline $\begin{array}{l}\text { Вакантные места по данным службы занятости, конец } 06.2020, \\
\text { чел. }\end{array}$ & $\mathbf{0 , 8 0}$ \\
\hline Разводов 01.-06.2020 & $\mathbf{0 , 8 0}$ \\
\hline Браков, 01.-06.2020 & $\mathbf{0 , 7 9}$ \\
\hline Расходы - соцподдержка в регионе на 06.2020 г., тыс.руб. & $\mathbf{0 , 7 9}$ \\
\hline $\begin{array}{l}\text { Зарегистрировано преступлений, совершенных иностранными } \\
\text { гражданами и лицами б/г на 07.2020 г. (01.20-07.20) }\end{array}$ & 0,79 \\
\hline Поступило от субъекта, I п/г 2020, тыс.руб. & $\mathbf{0 , 7 8}$ \\
\hline Задолженность региона по налогам, всего, I п/г 2020, тыс. руб. & $\mathbf{0 , 7 7}$ \\
\hline $\begin{array}{l}\text { Задолженность региона по федеральным налогам, I п/г, 2020, } \\
\text { тыс.руб. }\end{array}$ & $\mathbf{0 , 7 6}$ \\
\hline Занятых, т.ч., май-июль & 0,76 \\
\hline $\begin{array}{l}\text { Работающих трудоспособного возраста 15-72 лет, тыс. чел. } \\
(01 .-06.20)\end{array}$ & $\mathbf{0 , 7 6}$ \\
\hline Кол-во преступлений, 01.-07.2020 (01.20-07.20) & 0,76 \\
\hline Кол-во рабочей силы, тыс.чел. (15-72 лет, 01-06.20) & $\mathbf{0 , 7 5}$ \\
\hline Врачей на начало 2019 & $\mathbf{0 , 7 3}$ \\
\hline $\begin{array}{l}\text { Задолженность региона по региональным налогам, I п/г, 2020, } \\
\text { тыс. руб. }\end{array}$ & $\mathbf{0 , 7 3}$ \\
\hline Число койко-мест, на нач.2019г & $\mathbf{0 , 7 3}$ \\
\hline Умерших 01.-06.2020, чел. & $\mathbf{0 , 7 2}$ \\
\hline Неработающих пенсионеров на 1.01.20, тыс.чел. & $\mathbf{0 , 7 1}$ \\
\hline Родившихся 01.-06.2020, чел. & $\mathbf{0 , 7 0}$ \\
\hline
\end{tabular}


Окончание табл. 4.

\begin{tabular}{|l|c|}
\hline Больничных учреждений на конец 2019 г. & 0,67 \\
\hline $\begin{array}{l}\text { Поступило в федеральный бюджет от субъекта I п/г 2020, } \\
\text { тыс. руб. }\end{array}$ & 0,66 \\
\hline $\begin{array}{l}\text { Число самостоятельных организаций высшего образования, } \\
2019 \text { г. }\end{array}$ & 0,65 \\
\hline $\begin{array}{l}\text { Кол-во студентов в организациях высшего образования, } \\
\text { чел., 2019 }\end{array}$ & 0,61 \\
\hline Выпущено из организаций высшего образования, чел., 2019 & 0,60 \\
\hline Безработных, тыс.чел., май-июль 2020 & 0,56 \\
\hline Средний депозит домохозяйства (2920, II кв.), руб. & 0,55 \\
\hline $\begin{array}{l}\text { Безработных трудоспособного возраста, 15-72 лет, тыс. чел. } \\
\text { (01.-0б.20) }\end{array}$ & 0,55 \\
\hline Среднемесячный доход на душу насел., I п/г 2020, руб. & 0,53 \\
\hline $\begin{array}{l}\text { Потребительские среднемесячные расходы на душу насел., I п/г } \\
\text { 2020, руб. }\end{array}$ & 0,52 \\
\hline Потребление на одного члена семьи, I кв. 2020, руб. & 0,48 \\
\hline Умерших с диагнозом СОVID-19 за 06.20, чел. & 0,46 \\
\hline Преступлений террористических на 07.2020 (01.20-07.20) & 0,45 \\
\hline Расходы домохозяйств, І кв. 2020, отдых-, \% & 0,41 \\
\hline $\begin{array}{l}\text { Начисленная заработная плата работников организаций, I п/г } \\
\text { 2020, руб. }\end{array}$ & 0,41 \\
\hline Умерших с диагнозом СОVID- 19 за 05.2020, чел. & 0,40 \\
\hline Средняя заработная плата, 2020, май, руб. & 0,40 \\
\hline Средняя задолженность домохозяйства (2020, II кв.), руб. & 0,38 \\
\hline Среднегодовой доход домохозяйства, руб. (2020, II кв.) & 0,37 \\
\hline Врачей в сельской местности, на начало 2019 г & $-0,30$ \\
\hline Преступлений экстремистских на 07.2020г. (01.20-07.20). & 0,34 \\
\hline Расходы домохозяйств, І кв. 2020, питание, \% & \\
\hline
\end{tabular}

Важнейшим показателем благополучия региона являются доходы и расходы консолидированного бюджета. Рассмотрим профили регионов, имеющих высокие доходы и расходы консолидированного бюджета. Регионы с высокими доходами консолидированного бюджета характеризуются развитыми мерами социальной поддержки, большим числом вакантных рабочих мест, высокой брачной и репродуктивной активностью населения, хорошо развитой социальной сферой, обширным потоком внешних трудовых мигрантов, низкими расходами домохозяйств на питание. Обозначим данный профиль как 1 в. (Таблица 5). 
Таблиияа 5.

Корреляция показателя «консолидированный бюджет, доходы (I-е полугодие 2020 г.)» и иных факторов (коэффициент Спирмена, p, при р<0,05) по убыванию

\begin{tabular}{|c|c|}
\hline Взаимозависимые факторы по 85-ти регионам & $\begin{array}{c}\text { Консолиди- } \\
\text { рованный } \\
\text { бюджет - до- } \\
\text { ходы, } 1 \text { п/г } \\
2020, \text { тыс. p. }\end{array}$ \\
\hline Расходы, соцподдержка в регионе на 12.2019, тыс.руб. & $\mathbf{0 , 9 1}$ \\
\hline Расходы, соцподдержка в регионе на 06.2020, тыс.руб. & $\mathbf{0 , 9 0}$ \\
\hline Требуемых работников, I кв. 2020, тыс. чел & $\mathbf{0 , 8 8}$ \\
\hline Браков, 01.-06.2020. & $\mathbf{0 , 8 7}$ \\
\hline Оборот пищевых продуктов, январь-июнь, 2020, млн. руб. & $\mathbf{0 , 8 7}$ \\
\hline $\begin{array}{l}\text { Количество фактов снятия с миграционного учета (01.20-06.20), } \\
\text { чел. }\end{array}$ & $\mathbf{0 , 8 4}$ \\
\hline Родившихся 01.-06.2020, чел. & $\mathbf{0 , 8 3}$ \\
\hline Мигранты с целью работы внешние (01.20-06.20), чел. & $\mathbf{0 , 8 3}$ \\
\hline Кол-во рабочей силы, тыс.чел. (15-72 лет, 01-06.20) & $\mathbf{0 , 8 3}$ \\
\hline $\begin{array}{l}\text { Количество фактов постановок на миграционный учет } \\
(01.20-06.20) \text {, чел. }\end{array}$ & $\mathbf{0 , 8 2}$ \\
\hline $\begin{array}{l}\text { Работающих трудоспособного возраста 15-72 лет, тыс.чел. } \\
\text { (01.-06.20) }\end{array}$ & $\mathbf{0 , 8 2}$ \\
\hline Врачей на начало 2019 & $\mathbf{0 , 8 2}$ \\
\hline Разводов 01.-06.2020. & $\mathbf{0 , 8 2}$ \\
\hline $\begin{array}{l}\text { Преступлений в отношении иностранных граждан и лиц } \\
\text { без гражданства на 07.2020 г. (01.20-07.20) }\end{array}$ & $\mathbf{0 , 8 1}$ \\
\hline Число койко-мест, на нач.2019 & $\mathbf{0 , 8 1}$ \\
\hline Кол-во преступлений, 01.-07.2020 (01.20-07.20) & $\mathbf{0 , 8 0}$ \\
\hline Неработающих пенсионеров на 1.01.20, тыс.чел. & $\mathbf{0 , 7 9}$ \\
\hline Вакантные места по данным службы занятости, конец 06.2020, чел & 0,79 \\
\hline Больничных учреждений на конец 2019 & $\mathbf{0 , 7 8}$ \\
\hline Умерших 01.-06.2020, чел. & $\mathbf{0 , 7 2}$ \\
\hline $\begin{array}{l}\text { Зарегистрировано преступлений, совершенных иностранными } \\
\text { гражданами и лицами б/г на 07.2020 (01.20-07.20) }\end{array}$ & $\mathbf{0 , 7 0}$ \\
\hline Кол-во студентов в организациях высшего образования, чел., 2019 & 0,69 \\
\hline Число самостоятельных организаций высшего образования, 2019 & 0,69 \\
\hline $\begin{array}{l}\text { Безработных трудоспособного возраста, 15-72 лет, тыс.чел. } \\
\text { (01.-06.20) }\end{array}$ & 0,66 \\
\hline Средний депозит домохозяйства (2920, II кв.), руб. & 0,56 \\
\hline Среднемесячный доход на душу насел., I п/г 2020, руб. & 0,51 \\
\hline
\end{tabular}


Окончание табл. 5.

\begin{tabular}{|l|c|}
\hline $\begin{array}{l}\text { Потребительские среднемесячные расходы на душу населения, } \\
\text { I п/г 2020, руб. }\end{array}$ & 0,49 \\
\hline Преступлений террористических на 07.2020 (01.20-07.20) & 0,47 \\
\hline Потребление на одного члена семьи, І кв. 2020, руб. & 0,45 \\
\hline Среднегодовой доход домохозяйства, руб. (2020, II кв.) & 0,44 \\
\hline Расходы домохозяйств, І кв. 2020, отдых-, \% & 0,43 \\
\hline $\begin{array}{l}\text { Начисленная заработная плата работников организаций, I п/г } \\
\text { 2020, руб. }\end{array}$ & 0,42 \\
\hline Средняя задолженность домохозяйства (2020, II кв.), руб. & 0,42 \\
\hline Расходы домохозяйств, І кв. 2020, образование, \% & 0,31 \\
\hline Преступлений экстремистских на 07.2020г. (01.20-07.20). & 0,31 \\
\hline Расходы домохозяйств - І кв. 2020, транспорт, \% & 0,28 \\
\hline Доля домохозяйств с выходом в Интернет (\%), 2019 & 0,26 \\
\hline $\begin{array}{l}\text { Минимальный набор товаров и услуг для сравнения покупатель- } \\
\text { ской способности, июнь 2020, руб. }\end{array}$ & 0,25 \\
\hline Расходы домохозяйств, І кв. 2020, питание, \% & $-0,34$ \\
\hline
\end{tabular}

Данному профилю близки и регионы с высокими расходами консолидированного бюджета, назовем данный профиль 1 г. (Таблица 6).

Таблицуа 6.

Корреляция показателя «консолидированный бюджет, расходы (I полугодие 2020 г.)» и иных факторов (коэффициент Спирмена, p, при р<0,05) по убыванию

\begin{tabular}{|l|c|}
\hline \multicolumn{1}{|c|}{ Взаимозависимые факторы по 85-ти регионам } & $\begin{array}{c}\text { Консолиди- } \\
\text { рованный } \\
\text { бюджет - pac- } \\
\text { ходы, I п/г } \\
2020, \text { тыс. p. }\end{array}$ \\
\hline Расходы - соцподдержка в регионе на 12.2019 г., тыс.руб. & $\mathbf{0 , 9 2}$ \\
\hline Расходы - соцподдержка в регионе на 06.2020 г., тыс.руб. & $\mathbf{0 , 9 1}$ \\
\hline Требуемых работников, І кв. 2020, тыс. чел. & $\mathbf{0 , 8 9}$ \\
\hline Браков, 01.-06.2020. & $\mathbf{0 , 8 9}$ \\
\hline Оборот пищевых продуктов, январь-июнь, 2020, млн. руб. & $\mathbf{0 , 8 8}$ \\
\hline Родившихся 01.-06.2020, чел. & $\mathbf{0 , 8 5}$ \\
\hline Кол-во рабочей силы, тыс.чел. (15-72 лет, 01-06.20) & $\mathbf{0 , 8 5}$ \\
\hline $\begin{array}{l}\text { Работающих трудоспособного возраста, 15-72 лет, тыс.чел. } \\
\text { (01.-06.20) }\end{array}$ & $\mathbf{0 , 8 5}$ \\
\hline Разводов 01.-06.2020. & $\mathbf{0 , 8 5}$ \\
\hline Врачей на начало 2019 & $\mathbf{0 , 8 4}$ \\
\hline
\end{tabular}


Окончание табл. 6.

\begin{tabular}{|c|c|}
\hline $\begin{array}{l}\text { Количество фактов снятия с миграционного учета } \\
(01.20-06.20) \text {, чел. }\end{array}$ & $\mathbf{0 , 8 4}$ \\
\hline Число койко-мест, на нач.2019 & 0,84 \\
\hline $\begin{array}{l}\text { Количество фактов постановки на миграционный учет } \\
(01.20-06.20) \text {, чел. }\end{array}$ & $\mathbf{0 , 8 3}$ \\
\hline Мигранты с целью работы внешние (01.20-06.20), чел. & $\mathbf{0 , 8 2}$ \\
\hline Неработающих пенсионеров на 1.01.20, тыс.чел. & $\mathbf{0 , 8 2}$ \\
\hline Кол-во преступлений, 01.-07.2020 (01.20-07.20) & $\mathbf{0 , 8 2}$ \\
\hline $\begin{array}{l}\text { Преступлений в отношении иностранных граждан и лиц } \\
\text { без гражданства на } 07.2020 \text { г. (01.20-07.20) }\end{array}$ & 0,82 \\
\hline Больничных учреждений на конец 2019 & $\mathbf{0 , 8 1}$ \\
\hline $\begin{array}{l}\text { Вакантных мест по данным службы занятости, конец } 06.2020, \\
\text { чел }\end{array}$ & $\mathbf{0 , 8 1}$ \\
\hline Умерших 01.-06.2020, чел. & 0,75 \\
\hline $\begin{array}{l}\text { Кол-во студентов в организациях высшего образования, чел., } \\
2019\end{array}$ & $\mathbf{0 , 7 2}$ \\
\hline $\begin{array}{l}\text { Зарегистрировано преступлений, совершенных иностранными } \\
\text { гражданами и лицами б/г на } 07.2020(01.20-07.20)\end{array}$ & 0,71 \\
\hline $\begin{array}{l}\text { Число самостоятельных организаций высшего образования, } \\
2019\end{array}$ & 0,71 \\
\hline Выпущено из организаций высшего образования, чел., 2019 & $\mathbf{0 , 7 0}$ \\
\hline $\begin{array}{l}\text { Безработных трудоспособного возраста, 15-72 лет, тыс.чел. } \\
(01 .-06.20)\end{array}$ & 0,69 \\
\hline Средний депозит домохозяйства (2920, II кв.), руб. & 0,54 \\
\hline Среднемесячный доход на душу насел., I п/г 2020, руб. & 0,49 \\
\hline Преступлений террористических на 07.2020 (01.20-07.20) & 0,46 \\
\hline $\begin{array}{l}\text { Потребит. среднемесячные расходы на душу насел., I п/г } 2020 \text {, } \\
\text { руб. }\end{array}$ & 0,46 \\
\hline Потребление на одного члена семьи, I кв. 2020, руб. & 0,44 \\
\hline Расходы домохозяйств - I кв. 2020, отдых-, \% & 0,44 \\
\hline $\begin{array}{l}\text { Начисленная заработная плата работников организаций, I п/г } \\
2020, \text { руб. }\end{array}$ & 0,42 \\
\hline Средняя задолженность домохозяйства (2020, II кв.), руб. & 0,41 \\
\hline Среднегодовой доход домохозяйства, руб. (2020, II кв.) & 0,40 \\
\hline Преступлений экстремистских на 07.2020г. (01.20-07.20). & 0,34 \\
\hline Расходы домохозяйств, I кв. 2020, образование, \% & 0,34 \\
\hline Расходы домохозяйств, I кв. 2020, питание, \% & $-0,35$ \\
\hline
\end{tabular}

Момент перехода социальной напряженности в локальный социальный взрыв отражает показатель «количество экстремистских 
преступлений в регионе» (Таблица 7). Данный тип регионов ближе к профилю № 2, обозначим его как 2 в.

Таблица 7.

\section{Корреляция показателя «количество раскрытых} экстремистских преступлений в регионе (январь-июль 2020 г.)»

и иных факторов (коэффициент Спирмена, p, при р<0,05)

по убыванию

\begin{tabular}{|l|c|}
\hline \multicolumn{1}{|c|}{ Взаимозависимые факторы по 85-ти регионам } & $\begin{array}{c}\text { Преступлений } \\
\text { экстремистских } \\
\text { на 07.2020 г. } \\
(01.20-07.20) .\end{array}$ \\
\hline Преступлений террористических на 07.2020 (01.20-07.20) & 0,52 \\
\hline $\begin{array}{l}\text { Число самостоятельных организаций высшего образования, } \\
2019\end{array}$ & 0,51 \\
\hline $\begin{array}{l}\text { Безработных трудоспособного возраста, 15-72 лет, тыс.чел. } \\
\text { (01.-06.20) }\end{array}$ & 0,48 \\
\hline Безработных, тыс.чел., май-июль 2020 & 0,48 \\
\hline Умерших 01.-06.2020, чел. & 0,47 \\
\hline $\begin{array}{l}\text { Кол-во студентов в организациях высшего образования, чел., } \\
2019\end{array}$ & 0,47 \\
\hline Выпущено из организаций высшего образования, чел., 2019 & 0,46 \\
\hline Неработающих пенсионеров на 1.01.20, тыс.чел. & 0,46 \\
\hline Кол-во рабочей силы, тыс. чел. (15-72 лет, 01-06.20) & 0,46 \\
\hline $\begin{array}{l}\text { Работающие трудоспособного возраста 15-72 лет, тыс.чел. } \\
\text { (01.-06.20) }\end{array}$ & 0,45 \\
\hline Задолженность региона по налогам, всего, І п/г 2020, тыс. р. & 0,45 \\
\hline $\begin{array}{l}\text { Зарегистрировано преступлений, совершенных } \\
\text { иностранными гражданами и лицами б/г на 07.2020. (01.20-07.20) }\end{array}$ & 0,45 \\
\hline $\begin{array}{l}\text { Преступлений в отношении иностранных граждан и лиц } \\
\text { без гражданства на 07.2020 г. (01.20-07.20) }\end{array}$ & 0,41 \\
\hline Требуемых работников - І кв., 2020, тыс. чел. & 0,40 \\
\hline $\begin{array}{l}\text { Вакантные места по данным службы занятости, конец } \\
\text { 06.2020, чел. }\end{array}$ & 0,37 \\
\hline
\end{tabular}

Таким образом, было выявлено два основных профиля регионов с риском роста социальной напряженности, из них профили 1 a, 1 б, 1 в, 1 г-характеризуют регионы-«доноры» или достаточно независимые в целом от экономики всей страны (или от федерального 
центра), с высоким уровнем потребления и более высоким уровнем жизни; профили 2 a, 2 б, 2 в - беднейшие регионы, характеризующиеся низким жизненных уровнем населения, высокой безработицей, высокими расходами на питание, высокой преступностью, большим числом учащейся молодежи, высокой демографической нагрузкой.

Покажем на графиках некоторые выявленные неочевидные корреляции показателей. Умеренная положительная корреляция присутствует между показателями «задолженность домохозяйств» и среднегодовой доход домохозяйств (Рис. 1).

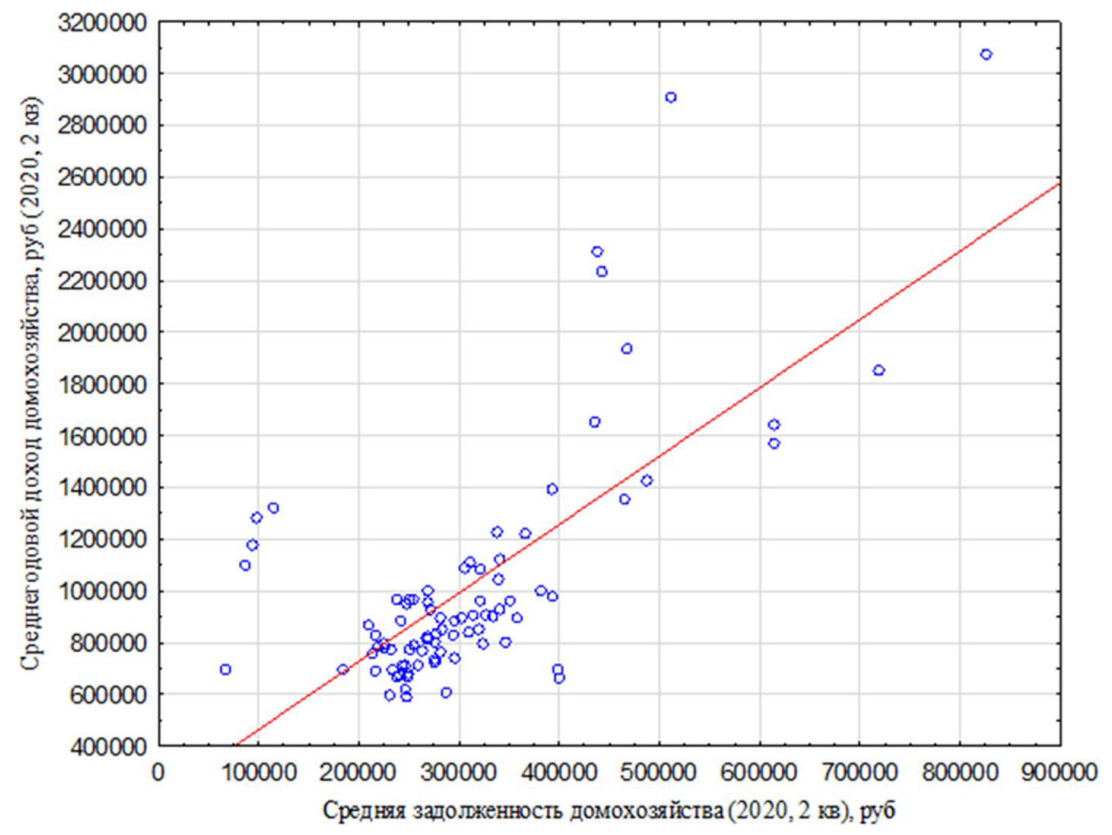

Рис. 1. Корреляция между показателями «задолженность домохозяйств» и «среднегодовой доход домохозяйств» во II квартале 2020 г. $(\mathrm{p}=0,55$, при $\mathrm{p}<0,05)$

Сильная положительная связь присутствует между показателем «задолженность домохозяйств» и величинами начисленной заработной платы в первом полугодии 2020 г. (Рис. 2).

Умеренная положительная связь присутствует между показателями «задолженность домохозяйств» и «среднемесячный доход до- 
мохозяйств», а также «ежемесячные потребительские расходы на душу населения» (Рис. 3, Рис. 4).

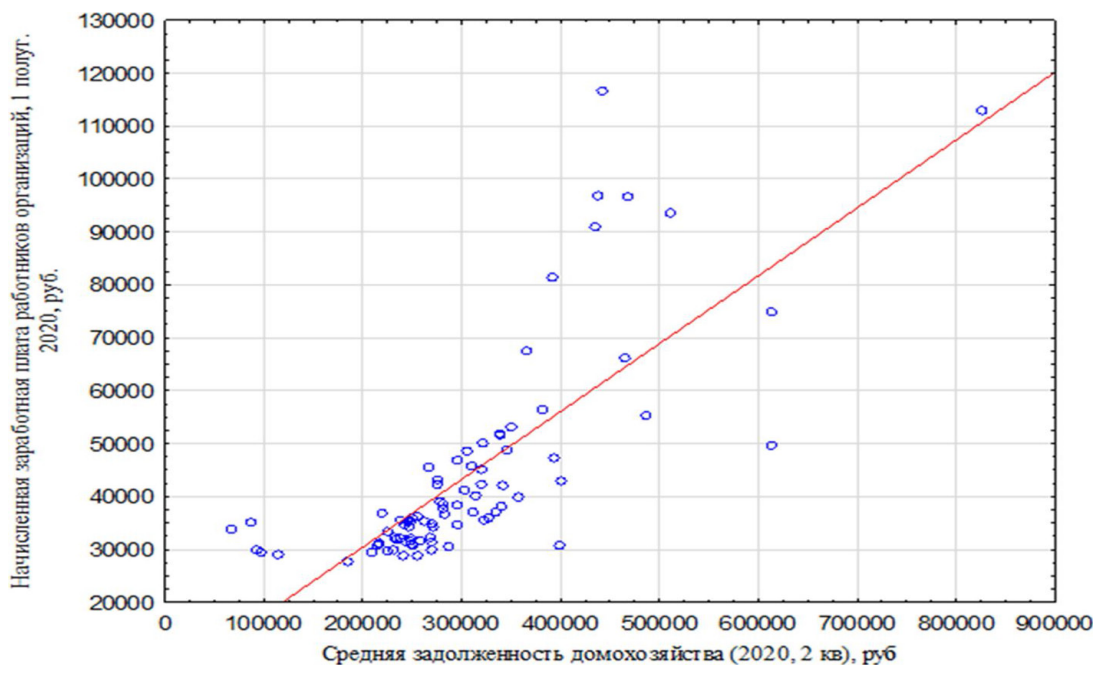

Рис. 2. Корреляция между показателями «задолженность домохозяйств» и «начисленная заработная плата работников организаций» (I полугодие 2020 г.) $(\mathrm{p}=\mathbf{0 , 8 2}$, при $\mathrm{p}<0,05)$

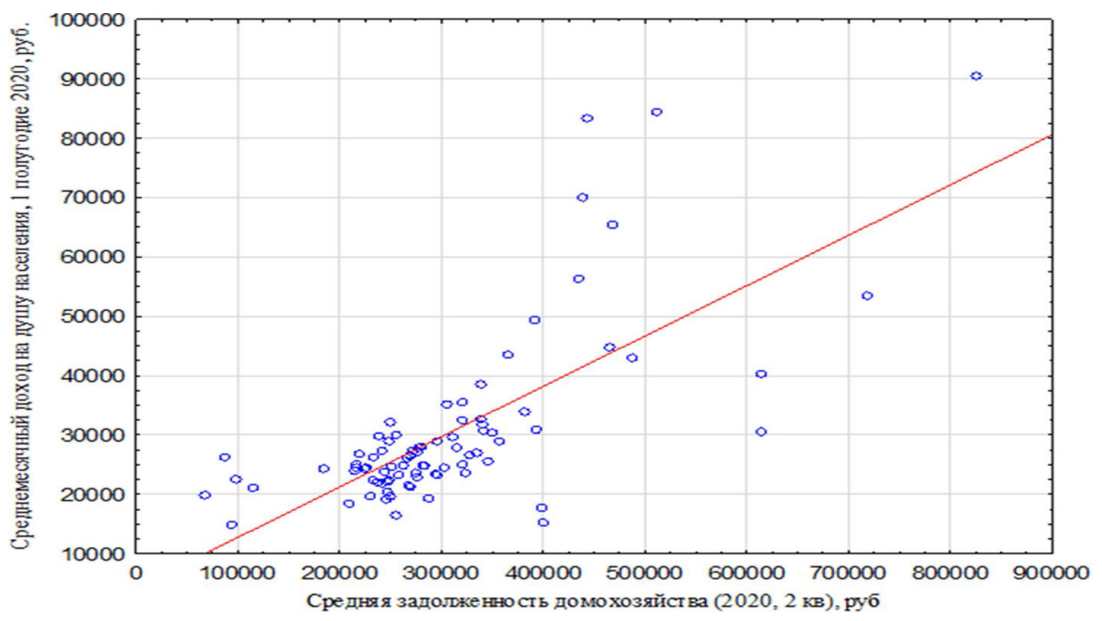

Рис. 3. Корреляция между показателями «задолженность домохозяйств» и «среднемесячные доходы на душу населения» (І полугодие 2020 г.)

$$
(\mathrm{p}=0,66, \text { при } \mathrm{p}<0,05)
$$




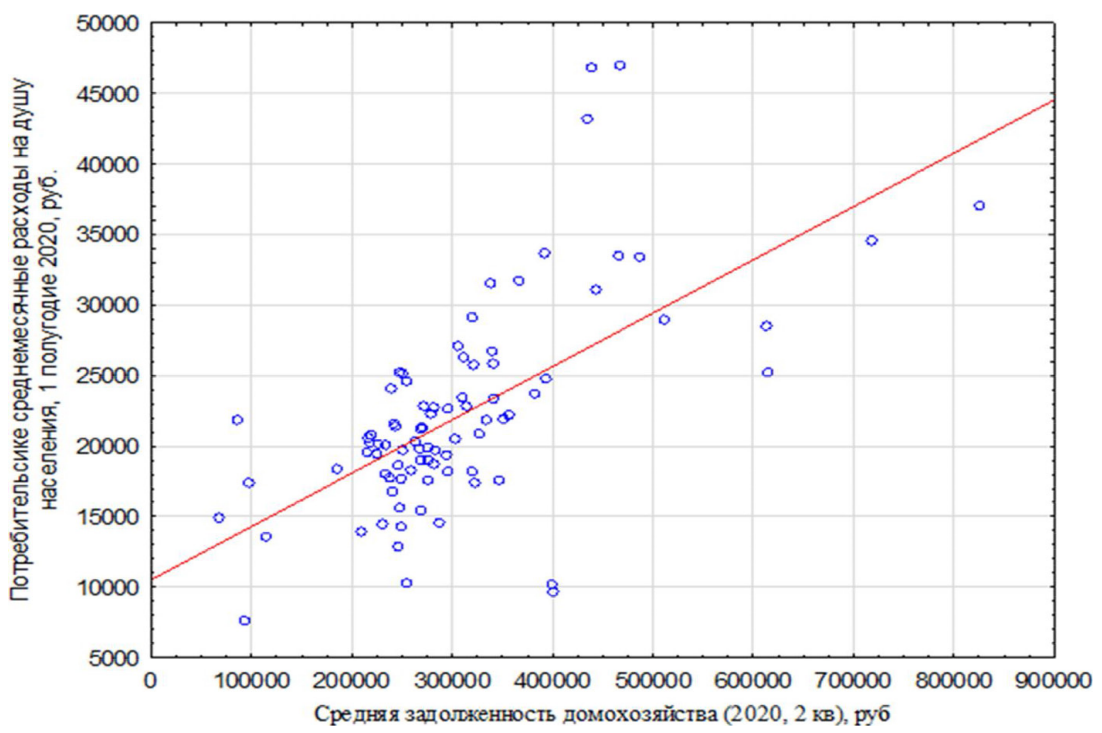

Рис. 4. Корреляция между показателями «задолженность домохозяйств» и «потребительские среднемесячные расходы на душу населения»

(І полугодие 2020 г.) (p = 0, 60, при $\mathrm{p}<0,05)$

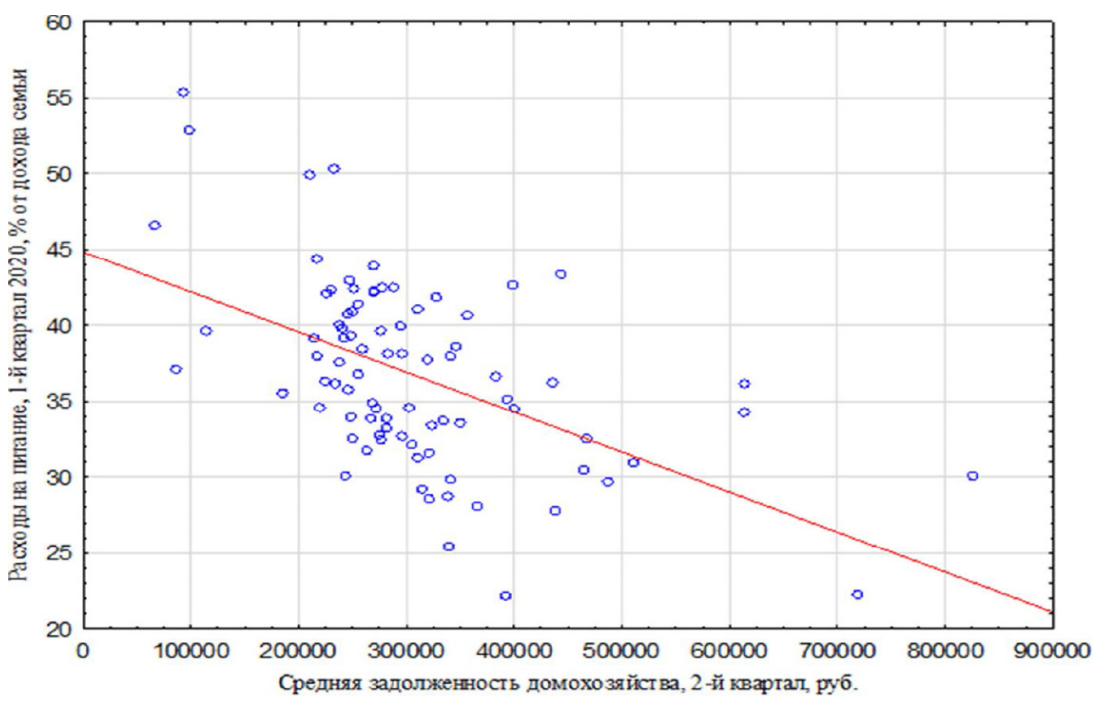

Рис. 5. Корреляция между показателями «задолженность домохозяйств» и «расходы домохозяйств на питание, $\%$ » $(\mathrm{p}=-0,52$, при $\mathrm{p}<0,05)$ 


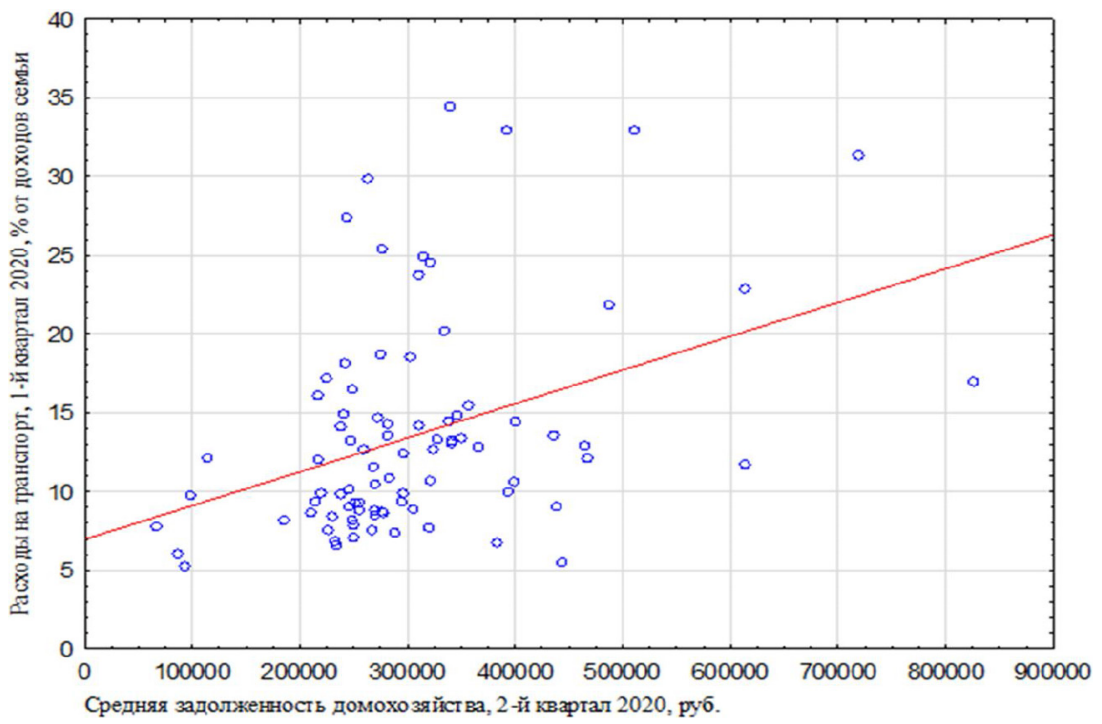

Рис. 6. Корреляция между показателями «задолженность домохозяйств» и «расходы домохозяйств на транспорт, \%» $(\mathrm{p}=0,40$, при $\mathrm{p}<0,05)$

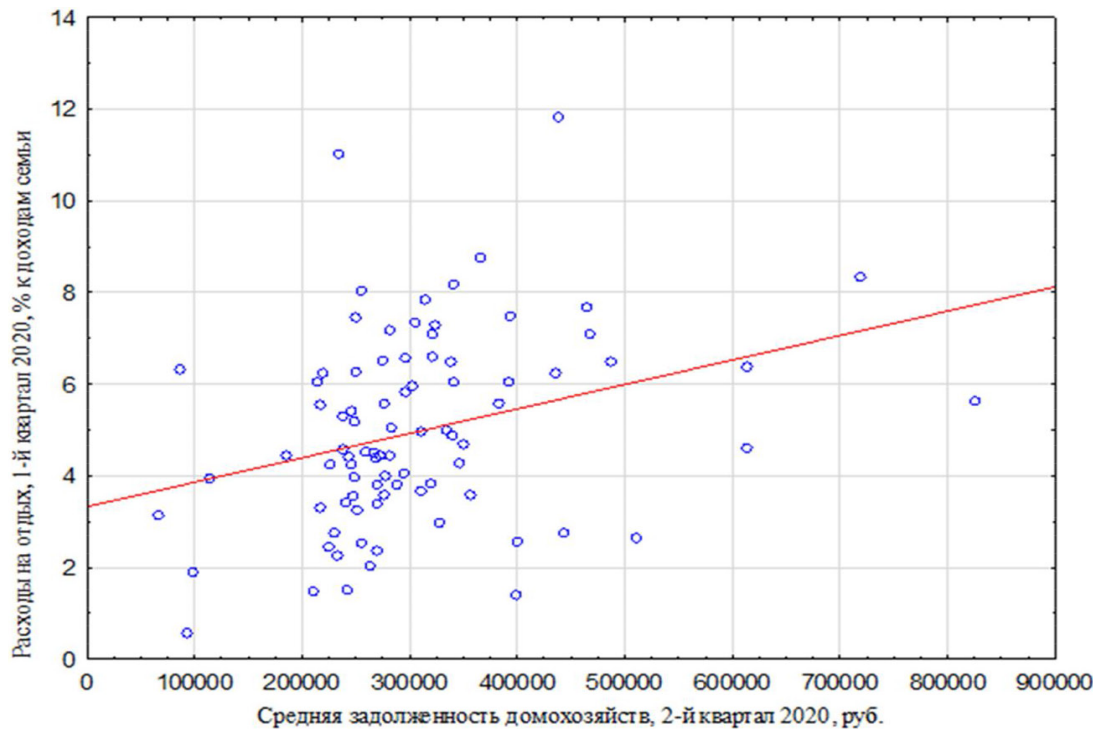

Рис. 7. Корреляция между показателями «задолженность домохозяйств» и «расходы домохозяйств на отдых, \%» $(\mathrm{p}=0,36$, при $\mathrm{p}<0,05)$ 
При умеренной положительной корреляции показателей «задолженность домохозяйств» и «расходы домохозяйств на транспорт», «расходы домохозяйств на отдых», «доля домохозяйств с выходом в интернет» (Рис. 5, Рис. 6, Рис. 7) имеется также умеренная отрицательная корреляционная связь имеется между показателями «задолженность домохозяйств» и «расходы домохозяйств на питание» (Рис. 8).

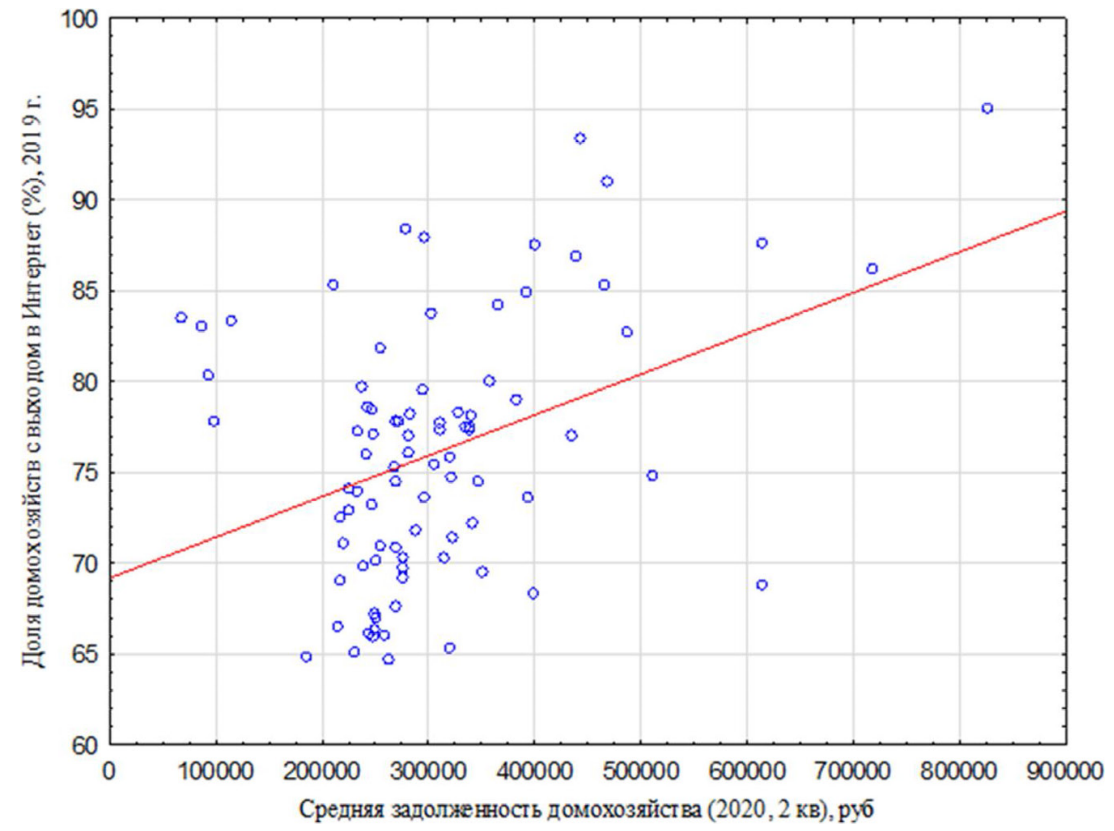

Рис. 8. Корреляция между показателями «задолженность домохозяйств» и «доля домохозяйств с выходом в Интернет» $(\mathrm{p}=0,32$, при $\mathrm{p}<0,05)$

Продемонстрируем графически умеренную положительную корреляцию между количеством экстремистских, террористических преступлений в регионе с количеством безработных трудоспособного возраста, количеством рабочей силы в регионе, а также количеством неработающих пенсионеров (что говорит о высокой демографической нагрузке на работающих граждан) (Рис. 9, Рис. 10, Рис. 11, Рис. 12). 


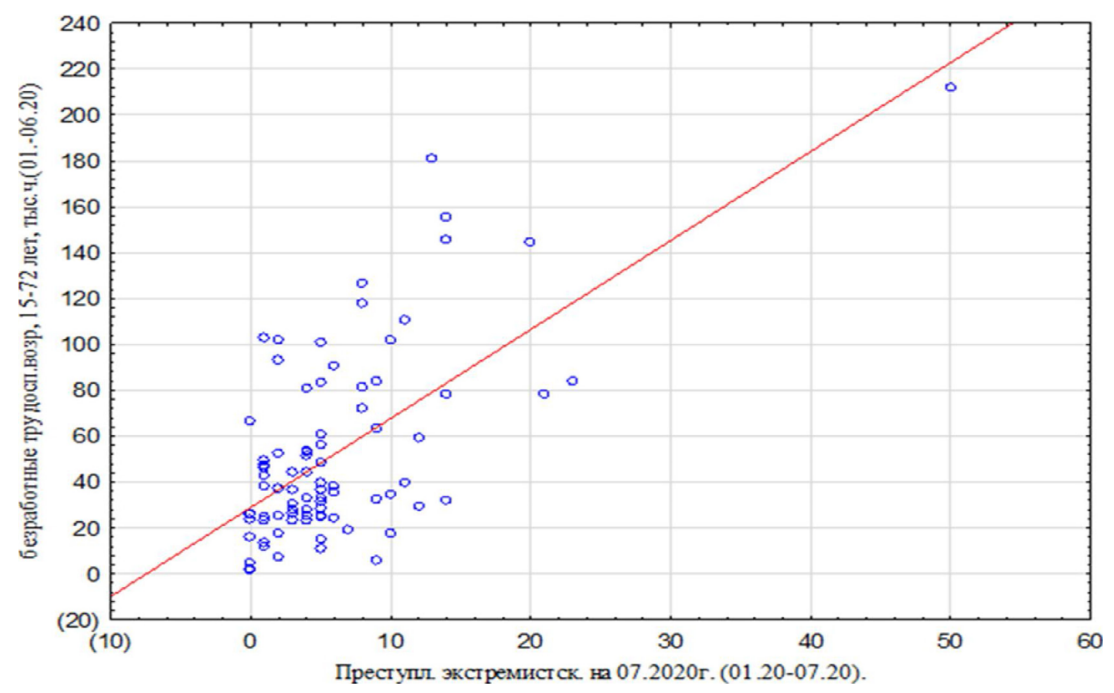

Рис. 9. Корреляция между показателями «количество экстремистских преступлений» и «количество безработных трудоспособного возраста» (І полугодие 2020 г.) $(\mathrm{p}=0$, 48, при $\mathrm{p}<0,05)$

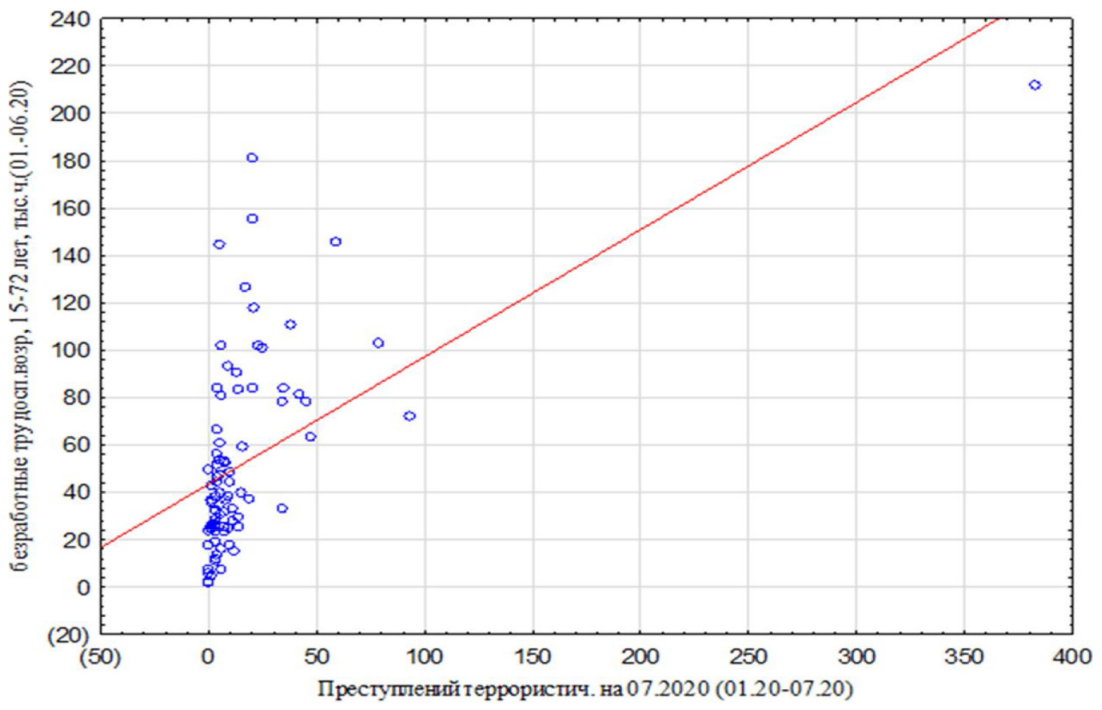

Рис. 10. Корреляция между показателями «количество террористических преступлений» и «количество безработных трудоспособного возраста» (І полугодие 2020 г.) (p = 0, 63, при p <0,05) 


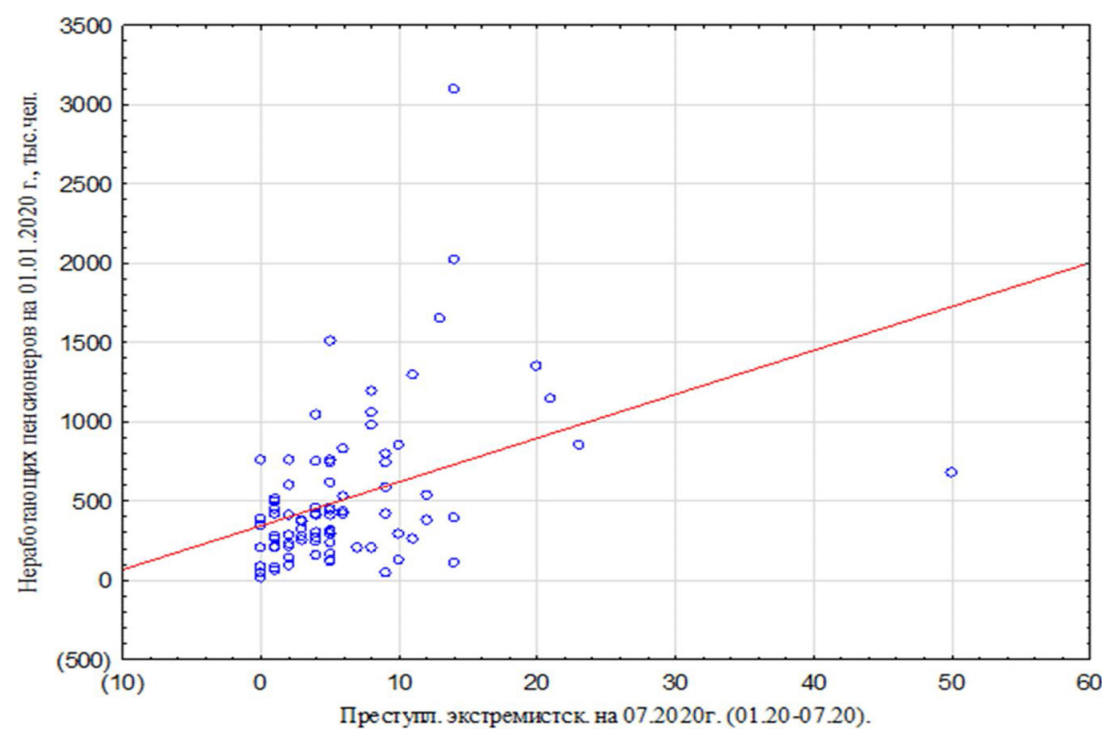

Рис. 11. Корреляция между показателями «количество экстремистских преступлений» и «количество неработающих пенсионеров» $(\mathrm{p}=0,46$, при $\mathrm{p}<0,05)$

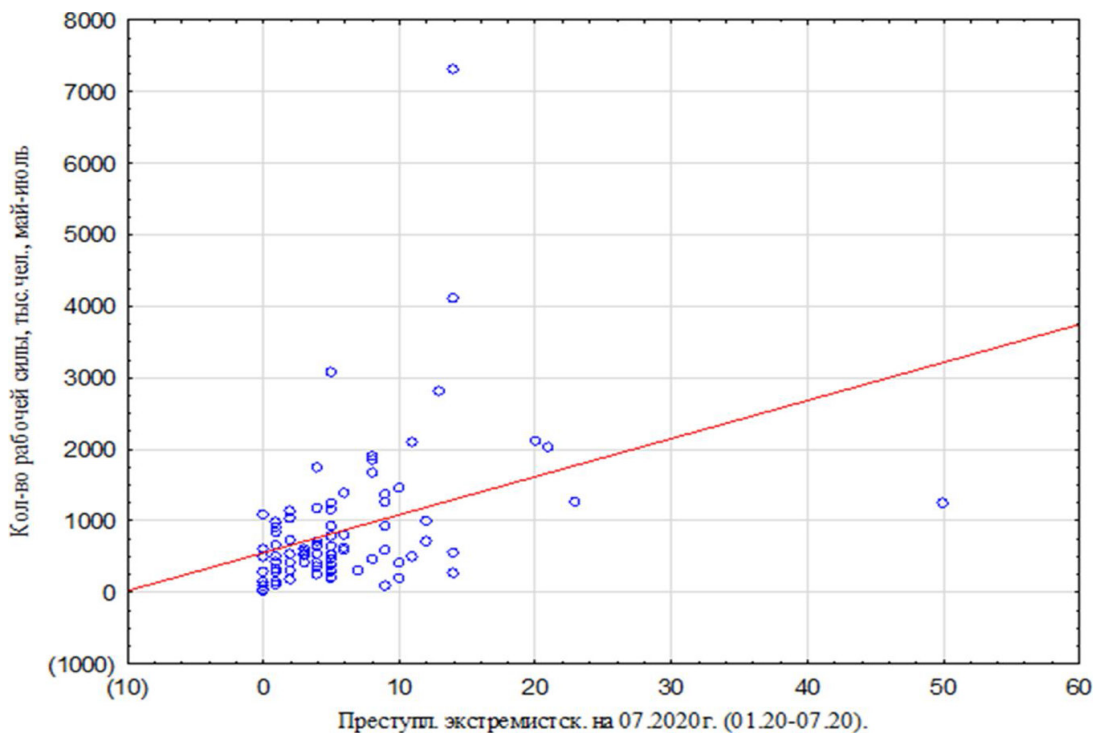

Рис. 12. Корреляция между показателями «количество экстремистских преступлений» и «количество рабочей силы» $(2020$ г.) $(\mathrm{p}=0$, 46, при $\mathrm{p}<0,05)$ 


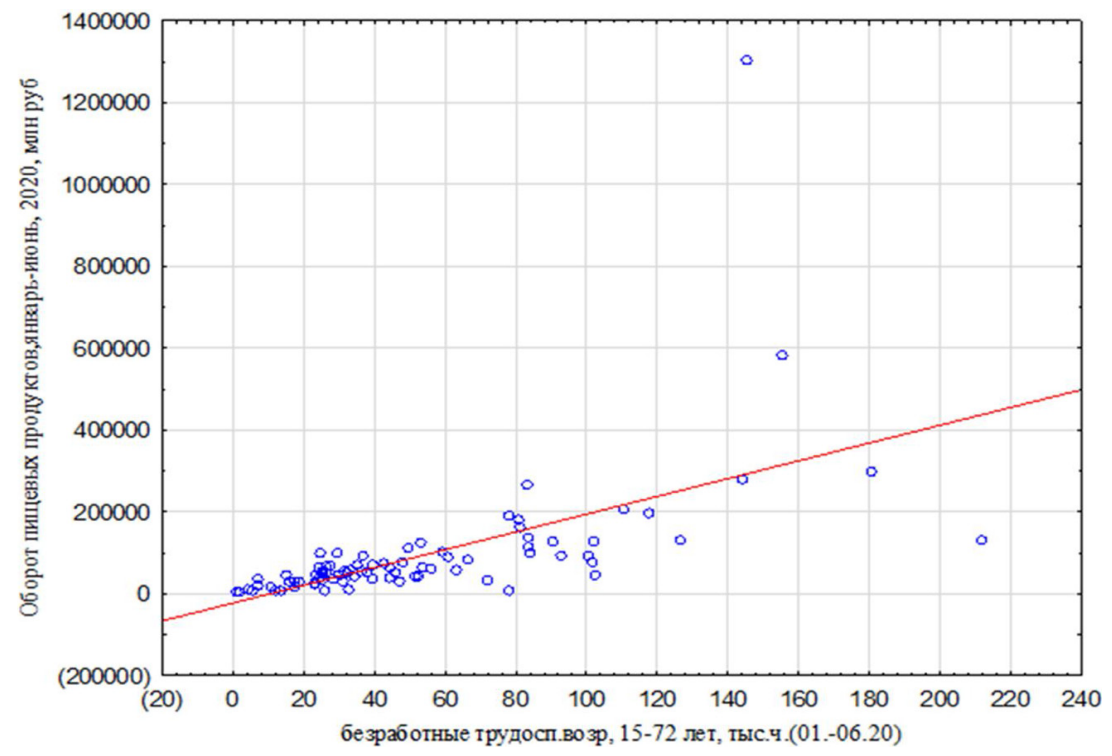

Рис. 13. Корреляция между количеством безработных трудоспособного возраста и оборотом пищевых продуктов (I полугодие 2020 г.) (p = 0, 77, при р $<0,05)$

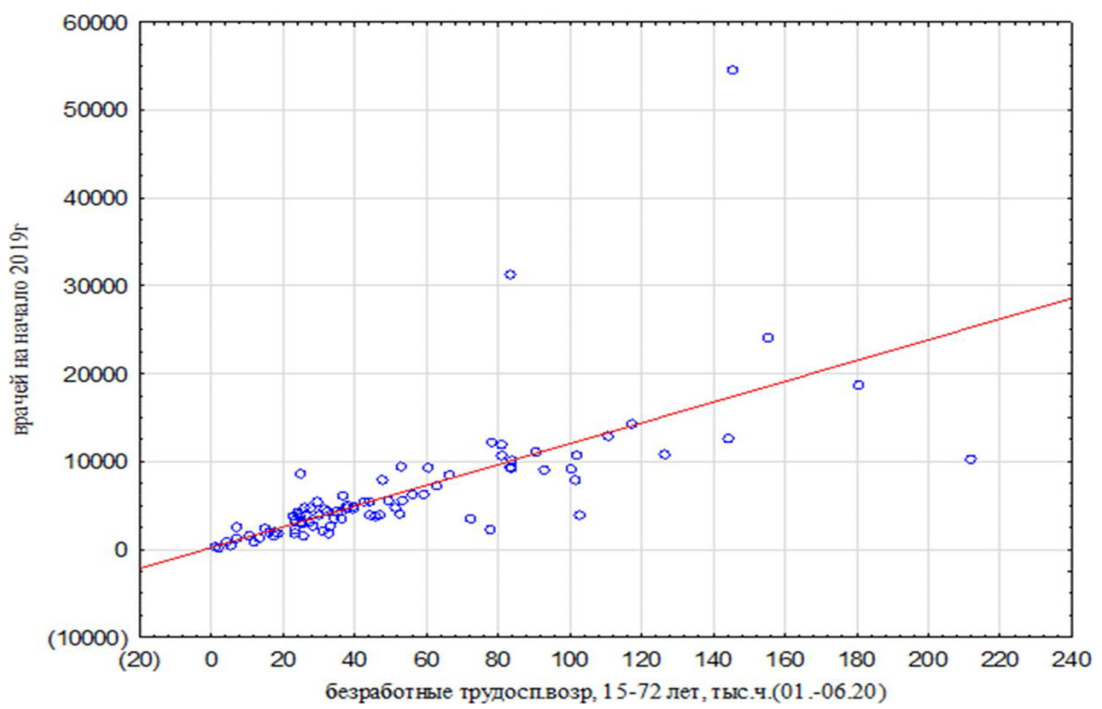

Рис. 14. Корреляция между количеством безработных трудоспособного возраста и количеством врачей в регионе $(\mathrm{p}=\mathbf{0}, \mathbf{8 6}$, при $\mathrm{p}<0,05)$ 


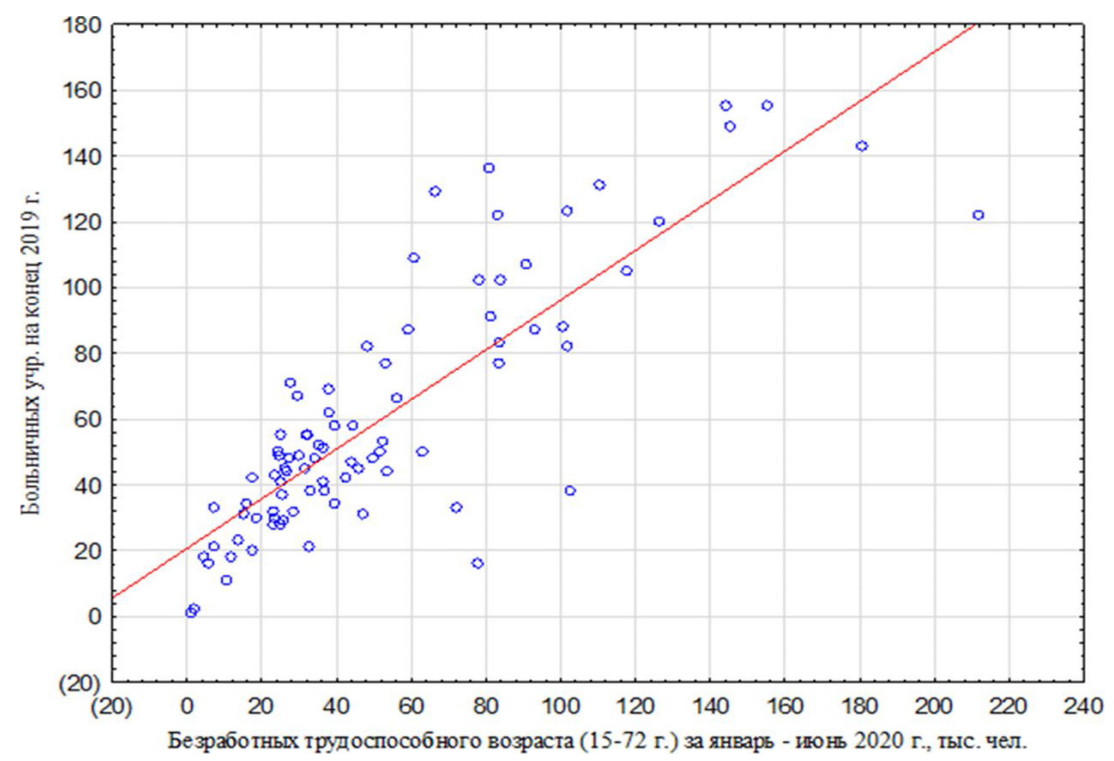

Рис. 15. Корреляция между количеством безработных трудоспособного возраста и количеством больничных учреждений в регионе $(\mathrm{p}=\mathbf{0}, \mathbf{8 0}$, при $\mathrm{p}<0,05)$

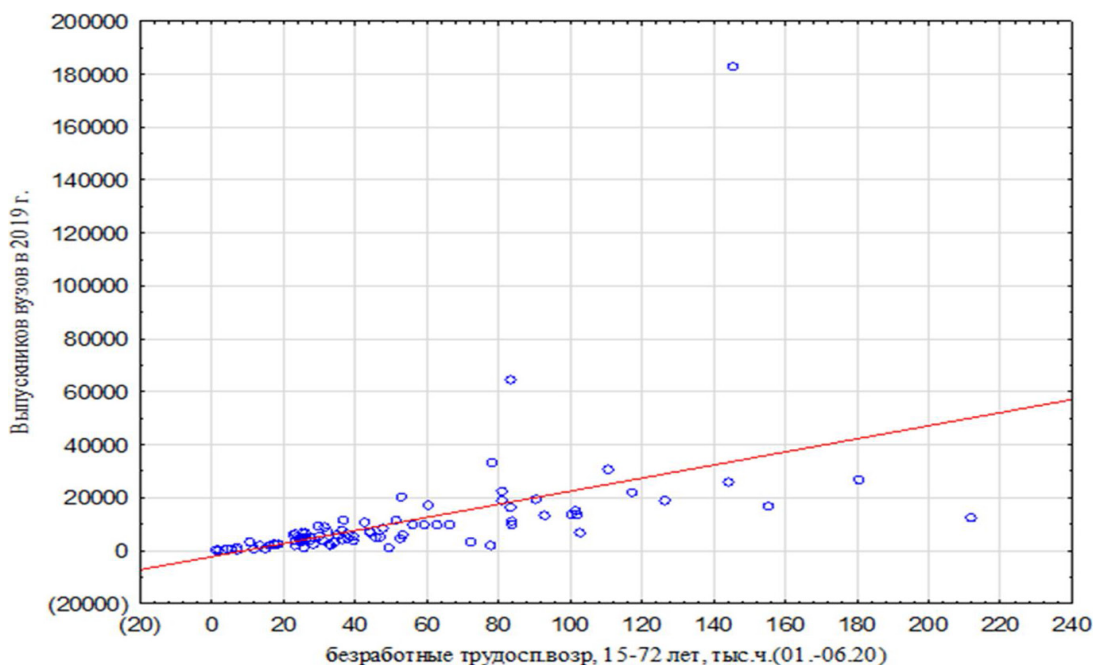

Рис. 16. Корреляция между количеством безработных трудоспособного возраста и количеством выпускников вузов предшествующего года в регионе $(\mathrm{p}=\mathbf{0}, \mathbf{8 1}$, при $\mathrm{p}<0,05)$ 


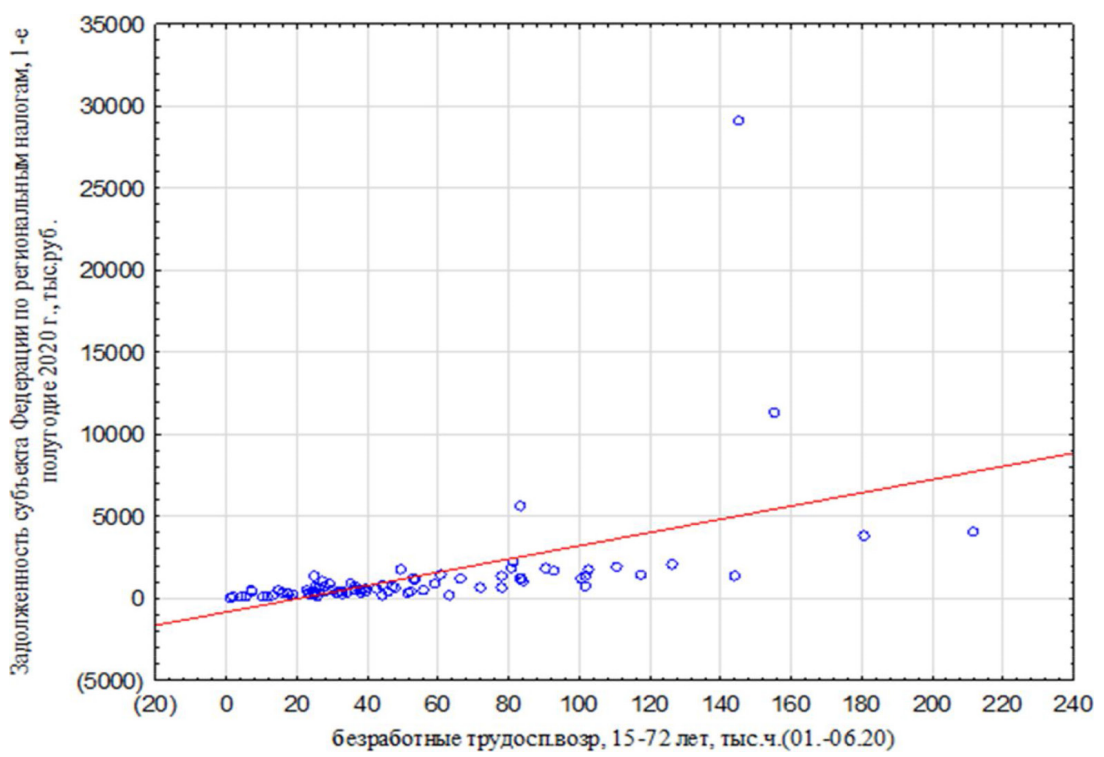

Рис. 17. Корреляция между количеством безработных трудоспособного возраста и задолженностью субъекта федерации по региональных налогам $(\mathrm{p}=\mathbf{0}, \mathbf{7 8}$, при $\mathrm{p}<0,05)$

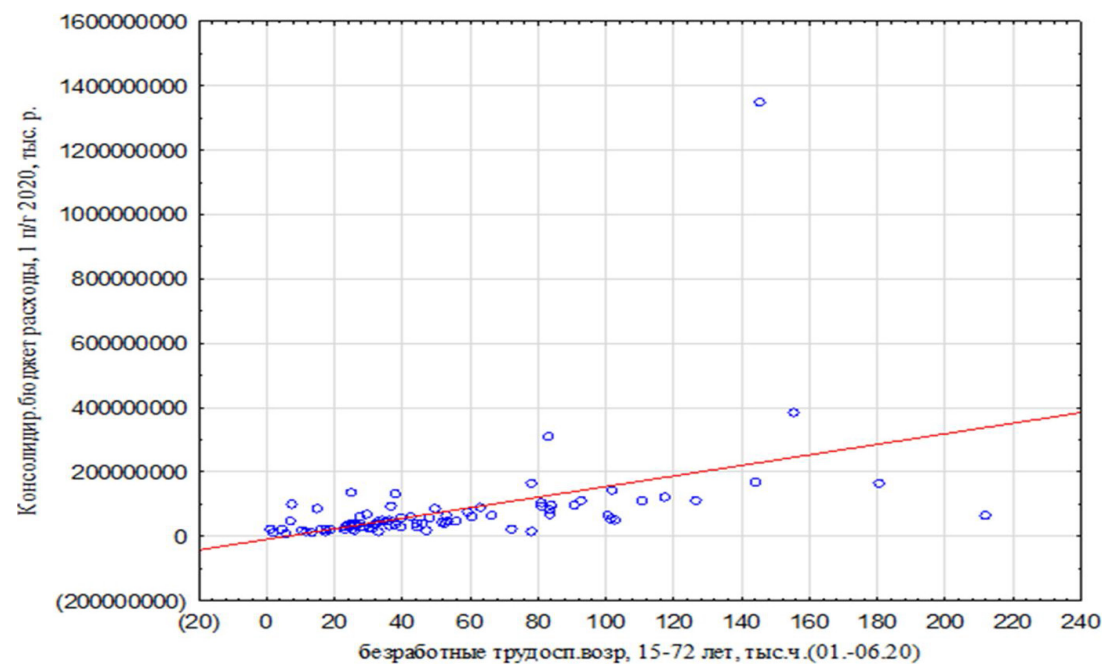

Рис. 18. Корреляция между количеством безработных трудоспособного возраста и расходами консолидированного бюджета в регионе $(\mathrm{p}=0,69$, при $\mathrm{p}<0,05)$ 
Продемонстрируем графически сильную положительную корреляцию количества безработных трудоспособного возраста и 1) оборота пищевых продуктов, 2) количества врачей и 3) больничных учреждений в регионе, 4) выпускников вузов, 5) задолженности субъекта федерации по региональных налогам (Рис. 13, Рис. 14, Рис. 15, Рис. 16, Рис. 17), а также умеренную положительную - 6) с расходами консолидированного бюджета в регионе (Рис. 18).

\section{Заключение}

Приведем предварительные выводы о профилях регионов с тенденцией к росту социальной напряженности и опишем основные условиях социально-экономической сферы в них.

1. Уровень расходов на питание и закредитованность населения как основные индикаторы риска роста социальной напряженности.

С помощью корреляционного анализа было подтверждено, что чем больше домохозяйство тратит на питание, тем одновременно в целом более выражен уровень бедности региона и, как правило, ниже в данном регионе вознаграждение на труд. Разновидностью профиля такого региона является также наличие большого количества безработных (формирование «протестной» безработицы в случае низкой оплаты труда и хорошо развитой социальной сферы). Также данные регионы характеризуются высокой демографической нагрузкой и риском протестных выступлений (более высокое число экстремистских и террористических преступлений).

В данный момент регионы сталкиваются с новым феноменом «люмпенизации»- массовой «протестной безработицей» (или уходом населения в «серую зону» экономики) в субъектах Российской Федерации с хорошо развитой социальной сферой и низкой оплатой труда: при уменьшении оплаты за труд, снижении стоимости минимальной потребительской корзины, а также при повышении доступности социальных благ, в том числе высшего образования, гарантированного бесплатного медицинского обслуживания, при низких расходах на ЖКХ и транспортные услуги растет количество безработных трудоспособного возраста. 
Задолженность домохозяйств в регионе не является отражением уровня бедности: она повышается в регионах при росте общего дохода домохозяйств, в случае высоких показателей валового регионального продукта, более высоких затрат домохозяйств на транспорт и на отдых. Таким образом, кредитная задолженность свойственна регионам с привычкой к «раскованному» потреблению, где больший процент населения по уровню доходов ранее мог быть близок к условному среднему классу и пытается поддержать высокий уровень жизни, несмотря на экономический кризис. Разновидностью профиля данного типа являются регионы с существенными потоками внешних трудовых мигрантов и ростом этно-социальной напряженности, проявляющейся в том числе в высоком количестве преступлений как против иностранных граждан, так и совершенных самими иностранными гражданами. Данные регионы характеризуются хорошо развитыми мерами социальной поддержки, низкими расходами домохозяйств на продукты питания.

2. Протестная активность. Можно предположить, что вероятность перерастания социальной напряженности в социальный взрыв будет выше в регионах, уже имеющих (помимо обозначенных выше социально-экономических условий) высокое число специфических видов преступлений, связанных с оправданием насилия и национальной неприязнью при социальном взаимодействии, избираемых как терминальный способ решения социально-экономических и политических проблем.

Количество экстремистских преступлений выше в регионах, где высок уровень безработицы и демографической нагрузки (выше количество учащейся студенческой молодежи, неработающих пенсионеров), в регионах с большим процентом расходов домохозяйств на питание, с меньшей общей задолженностью домохозяйств. Для данных регионов присущи более низкая заработная плата, более высокий оборот пищевых продуктов. В регионах с высоким прожиточным минимумом, общим доходом домохозяйств, более высокой стоимостью минимальной корзины продуктов и услуг количество преступлений экстремистского характера статистически значимо ниже. 
Большее количество террористических преступлений характерно для тех регионов, где наблюдается также и рост преступлений против иностранных граждан и лиц без гражданства, то есть в тех регионах, где имеется выраженная этно-социальная напряженность, значим приток внешних трудовых мигрантов. Количество террористических преступлений растет в регионах Российской Федерации при снижении прожиточного минимума, снижении стоимости минимального набора товаров и услуг, наличии доступа домохозяйств в сеть Интернет. Террористических преступлений больше регистрируется в регионе, если в нем выше безработица в целом и за последние полгода, ниже средняя начисленная заработная плата, выше число студентов и организаций высшего образования, выше оборот пищевых продуктов (по нему можно выявить в том числе и число нелегалов, не стоящих на миграционном учете).

Таким образом, в процессе исследования было предварительно выявлено два основных профиля и семь подпрофилей регионов с риском роста социальной напряженности. Из них первый профиль представляют четыре подпрофиля (1 a, 1 б, 1 в, 1 г), характеризующие регионы с высоким уровнем потребления и более высоким уровнем жизни, существенными потоками внешних трудовых мигрантов, адекватными отчислениями в региональный и федеральный бюджет, развитыми мерами социальной поддержки населения, однако и с высокой закредитованностью населения. Три подпрофиля (2 a, 2 6, 2 в) представляют второй профиль и описывают беднейшие регионы, характеризующиеся низким уровнем жизни населения, низкой оплатой труда, высокой безработицей, высокими расходами на питание, высокой преступностью, большим числом учащейся молодежи, высокой демографической нагрузкой. Первый тип профиля регионов имеет тенденцию роста не только социальной, но и этно-социальной напряженности, проявляющейся в повышении количества преступлений против иностранных граждан. Второй тип профиля региона имеет тенденцию к росту числа экстремистских и террористических преступлений. 
Статья подготовлена в рамках Государственного задания ЦИПБ РАН на 2019 год и на плановый период 2020 и 2021 годы (НИР 0006-2020-0001).

\section{Список литературы}

1. Алексеёнок А. Социальное неравенство и социальная напряженность. Орел: Орловский фил. РАНХиГС, 2015. 243 с.

2. Баранова Г. В. Социальная напряженность и формы ее выражения: Региональные особенности. Орёл: Акад. ФСО России, 2015. 185 с.

3. Бараночников В. А. Социальная напряженность в условиях трансформации социальной структуры современного российского общества (на материалах Орловской области). Автореф... канд. социол. H. M., 2015. 24 c.

4. Внукова Л. Б. Социально-политическая напряженность в полиэтническом регионе. Ростов-на-Дону: ЮНЦ РАН, 2014. 191 с.

5. Грызлов И. Н. Методика обработки статистической информации для оценки индексов социальной напряженности в регионе. Автореф... канд. технич. н. М., 2012. 27 с.

6. Зубаревич Н. В. Будущее российского пространства: экономика и население // Будущее российской экономики. М.: «Эксмо», 2019. C. $177-184$.

7. Зубаревич Н., Макаренцева А., Мкртчян Н. Социально-демографические индикаторы: Региональное измерение (по результатам регулярного Мониторинга ИНСАП РАНХиГС) // Экономическое развитие России. 2017. № 3. С. 90-100.

8. Зубаревич Н.В. Бедность в российских регионах в 2000-2017 годах: факторы и динамика // Население и экономика. 2019. № 3. С. 63-74.

9. Зубаревич Н.В. Неравенство регионов и крупных городов России: Что изменилось в 2010-е годы? // Общественные науки и современность. 2019. № 4. С. 57-70.

10. Зубаревич Н.В. Регионы: экономика, занятость и доходы населения, состояние бюджетов // 2014-2015 годы: Экономический кризис социальное измерение. М.: Издательский дом «Дело» РАНХиГС, 2016. C. 37-53. 
11. Зубаревич Н.В. Социальная география российского кризиса // Общественные науки и современность. 2017. № 5. С. 5-8.

12. Зубаревич Н.В., Малева Т., Ляшок В. Социально-экономическая динамика и положение регионов в середине 2019 г. // Экономическое развитие России. 2019. Т. 26. № 9. С. 35-50.

13. Зубаревич Н.В., Сафронов С. Доля продуктов питания в структуре расходов населения регионов России как индикатор уровня жизни и модернизации потребления // Вестник Московского университета. Серия 5: География. 2019. № 2. С. 61-68.

14. Зубаревич Н.В., Сафронов С. Люди и деньги: доходы, потребление и финансовое поведение населения российских регионов в 2000-2017 гг. // Известия РАН. Серия географическая. 2019. № 5. С. 3-17.

15.Информация о социально-экономическом положении России. 20.08.2020 г. Январь-июль // Росстат. URL: https://rosstat.gov.ru/ compendium/document $/ 50800$

16. Комарова И.П., Сигарев А.В., Устюжанина Е.В. Дистанционная занятость в формируемой в России цифровой экономике: Уроки пандемии// Российский экономический журнал. № 4, 2020. С. 31-41. DOI: 10.33983/0130-9757-2020-4-31-41

17. Кондрашов Н. Макроэкономика. В мае кризис продолжился // Бюллетень «Комментарии о Государстве и Бизнесе». №296, 2020 г., 02.07.2020. С. 1-7. URL: https://dcenter.hse.ru/mirror/pubs/share/ direct/376449600.pdf

18. Миронов В., Коновалова Л., Кузнецов А. Макроэкономика. Выход из карантина: Эмоции бизнеса и реальность экономического спада // Бюллетень «Комментарии о Государстве и Бизнесе» №295, 2020 г., 23.06.2020. C. 1-11. URL: https://dcenter.hse.ru/mirror/pubs/share/ direct/374751528.pdf

19. Отдельные показатели миграционной ситуации в Российской Федерации за январь - июнь 2020 года с распределением по странам и регионам. 17 Июля 2020 г.// ГУ МВД. URL: https://xn--b1aew.xn-p1ai/Deljatelnost/statistics/migracionnaya/item/20643682/

20.Показатели преступности в Российской Федерации (январьиюль 2020 г.)// Портал правовой статистики. Генеральная проку- 
ратура Российской Федерации. URL: http://crimestat.ru/offenses table

21. Пухов С. Мировая экономика: Опережающие индикаторы: На пути к восстановлению экономического роста// Бюллетень «Комментарии о Государстве и Бизнесе»/ Институт «Центр развития» НИУ «Высшая школа экономики». №297, 2020 г., 07.07.2020 C. 1-9. URL: https:/dcenter.hse.ru/mirror/pubs/share/direct/377612119.pdf

22. Чернявский А. Бюджет. Вирус в регионах// Бюллетень «КГБ: Комментарии о Государстве и Бизнесе» №291, 2020 г., 16.06.2020. С. 1-6. URL: https://dcenter.hse.ru/mirror/pubs/share/direct/373271455.pdf

23. Чернявский А. Бюджет. Отрицательный майский баланс // Бюллетень «КГБ: Комментарии о Государстве и Бизнесе». №293, 2020 г., 22.06.2020. URL: https://dcenter.hse.ru/mirror/pubs/share/ direct/374630137.pdf

24. Ovcharova L., Gorina E. Developing Targeted Social Assistance in Russia: Impediments and Possibilities. Problems of Economic Transition. 2017. Vol. 59. No. 11-12. P. 843-864.

25.Zubarevich N. Economic, Social, and Budget Problems of the Russian Regions in 2013-2016. The Journal of Comparative Economic Studies. 2017. No. 12. P. 53-78.

26.Zubarevich N. Regional and Local Government. In bk.: Russia: Strategy, Policy and Administration. L.: Palgrave Macmillan, 2018. P. 367-380.

27.Zubarevich N. Regional Dimension of the New Russian Crisis. Social Sciences. 2015. Vol. 46. No. 4. P. 3-18.

28. Zubarevich N. Régions de Russie: sortie de crise et moteurs de croissance. In bk.: Russie 2017: Regards de 1'Observatoire franco-russe 2018. P.: Observo, 2018. P. 247-258.

29.Zubarevich N. The Relations Between the Center and the Regions In bk.: The State of Russia: What Comes Next? Houndmills: Palgrave Macmillan, 2015. P. 50-68.

30.Zubarevich N.V. Crises in post-Soviet Russia: Regional projection. Regional Research of Russia. 2016. Vol. 6. No. 2. P. 95-104.

31.Zubarevich N.V. Die Krise in den Regionen Russlands. Russland Analysen. 2016. No. 318. P. 2-8. 


\section{References}

1. Alekseenok A. Sotsial'noe neravenstvo i sotsial 'naya napryazhennost' [Social inequality and social tension]. Orel, 2015. 243 pp.

2. Baranova G. V. Sotsial'naya napryazhennost' i formy ee vyrazheniya: Regional'nye osobennosti [Social tension and forms of its expression]. Orel: Akad. FSO Rossii, 2015. 185 pp.

3. Baranochnikov V. A. Sotsial'naya napryazhennost'v usloviyakh transformatsii sotsial'noy struktury sovremennogo rossiyskogo obshchestva (na materialakh Orlovskoy oblasti) [Social tension in the context of the transformation of the social structure of modern Russian society (based on materials from the Oryol region)]. Avtoref... kand. sotsiol. n. M., 2015. 24 pp.

4. Vnukova L. B. Sotsial'no-politicheskaya napryazhennost'v polietnicheskom regione [Socio-political tension in the multi-ethnic region]. Rostov-na-Donu, 2014. $191 \mathrm{pp}$.

5. Gryzlov I. N. Metodika obrabotki statisticheskoy informatsii dlya otsenki indeksov sotsial'noy napryazhennosti v regione [Methodology for processing statistical information to assess the indices of social tension in the region]. Avtoref... kand. tekhnich. n. M., 2012. 27 pp.

6. Zubarevich N. V. Budushchee rossiyskogo prostranstva: ekonomika i naselenie [The future of the Russian space: economy and population]. Budushchee rossiyskoy ekonomiki [The future of the Russian economy]. M.: «Eksmo», 2019. P. 177-184.

7. Zubarevich N., Makarentseva A., Mkrtchyan N. Sotsial'no-demograficheskie indikatory: Regional'noe izmerenie [Socio-demographic indicators: Regional dimension]. Ekonomicheskoe razvitie Rossii. 2017. № 3. P. $90-100$.

8. Zubarevich N.V. Bednost' v rossiyskikh regionakh v 2000-2017 gg: faktory i dinamika [Poverty in Russian regions in 2000-2017: factors and dynamics]. Naselenie i ekonomika. 2019. № 3. P. 63-74.

9. Zubarevich N.V. Neravenstvo regionov i krupnykh gorodov Rossii: Chto izmenilos' v 2010-e gody? [Inequality of Regions and Large Cities of Russia: What Has Changed in the 2010s?]. Obshchestvennye nauki $i$ sovremennost’. 2019. № 4. P. 57-70. 
10. Zubarevich N.V. Regiony: ekonomika, zanyatost' i dokhody naseleniya, sostoyanie byudzhetov [Regions: economy, employment and income of the population, state of budgets]. 2014-2015 gody: Ekonomicheskiy krizis - sotsial'noe izmerenie [2014-2015: Economic crisis - social dimension]. M.: Izdatel'skiy dom «Delo», 2016. P. 37-53.

11. Zubarevich N.V. Sotsial'naya geografiya rossiyskogo krizisa [Social geography of the Russian crisis]. Obshchestvennye nauki i sovremennost'. 2017. № 5. P. 5-8.

12.Zubarevich N.V., Maleva T., Lyashok V. Sotsial'no-ekonomicheskaya dinamika i polozhenie regionov v seredine $2019 \mathrm{~g}$. [Socio-economic dynamics and position of regions in mid-2019]. Ekonomicheskoe razvitie Rossii. 2019. V. 26. № 9. P. 35-50.

13.Zubarevich N.V., Safronov S. Dolya produktov pitaniya v strukture raskhodov naseleniya regionov Rossii kak indikator urovnya zhizni i modernizatsii potrebleniya [The share of food products in the structure of expenses of the population of the regions of Russia as an indicator of the standard of living and modernization of consumption]. Vestnik Moskovskogo universiteta. Seriya 5: Geografiya. 2019. № 2. P. 61-68.

14.Zubarevich N.V., Safronov S. Lyudi i den'gi: dokhody, potreblenie i finansovoe povedenie naseleniya rossiyskikh regionov v 2000-2017 gg. [People and Money: Income, Consumption and Financial Behavior of the Population of Russian Regions in 2000-2017]. Izvestiya RAN. Seriya geograficheskaya. 2019. № 5. P. 3-17.

15. Informatsiya o sotsial'no-ekonomicheskom polozhenii Rossii. 20.08.2020 g. Yanvar'-iyul' [Information about the social and economic situation in Russia. 08/20/2020 January-July]. Rosstat. URL: https://rosstat.gov.ru/ compendium/document $/ 50800$

16. Komarova I.P., Sigarev A.V., Ustyuzhanina E.V. Distantsionnaya zanyatost' $\mathrm{v}$ formiruemoy $\mathrm{v}$ Rossii tsifrovoy ekonomike: Uroki pandemii [Distance employment in the emerging digital economy in Russia: Lessons from the pandemic]. Rossiyskiy ekonomicheskiy zhurnal. № 4. 2020. P. 31-41. DOI: 10.33983/0130-9757-2020-4-31-41

17. Kondrashov N. Makroekonomika. V mae krizis prodolzhilsya [The crisis continued in May]. Byulleten” "Kommentarii o Gosudarstve $i$ Biznese». 
№296, 2020 g., 02.07.2020. P. 1-7. URL: https://dcenter.hse.ru/mirror/ pubs/share/direct/376449600.pdf

18. Mironov V., Konovalova L., Kuznetsov A. Makroekonomika. Vykhod iz karantina: Emotsii biznesa i real'nost' ekonomicheskogo spada [Exiting Quarantine: Business Emotions and the Reality of Recession]. Byulleten' «Kommentarii o Gosudarstve i Biznese» №295, 2020, 23.06.2020. P. 1-11. URL: https://dcenter.hse.ru/mirror/pubs/share/direct/374751528.pdf

19. Otdel'nye pokazateli migratsionnoy situatsii $v$ Rossiyskoy Federatsii za yanvar' - iyun' 2020 goda s raspredeleniem po stranam i regionam. 17 Iyulya $2020 \mathrm{~g}$. [Selected indicators of the migration situation in the Russian Federation for January - June 2020 with distribution by country and region. 17 July 2020]. GU MVD. URL: https://xn--b1aew.xn--p1ai/ Deljatelnost/statistics/migracionnaya/item/20643682/

20.Pokazateli prestupnosti v Rossiyskoy Federatsii (yanvar'-iyul' 2020 g.) [Crime rates in the Russian Federation (January-July 2020)]. Legal statistics portal. General Prosecutor's Office of the Russian Federation. URL: http://crimestat.ru/offenses_table

21.Pukhov S. Mirovaya ekonomika: Operezhayushchie indikatory: Na puti k vosstanovleniyu ekonomicheskogo rosta [World Economy: Leading Indicators: Towards a Growth Recovery]. Byulleten' "Kommentarii o Gosudarstve $i$ Biznese»/ Institut «Tsentr razvitiya» NIU «Vysshaya shkola ekonomiki». №297, 2020, 07.07.2020 P. 1-9. URL: https://dcenter.hse. ru/mirror/pubs/share/direct/377612119.pdf

22. Chernyavskiy A. Byudzhet. Virus v regionakh [Virus in the regions]. Byulleten' “KGB: Kommentarii o Gosudarstve i Biznese» №291, 2020, 16.06.2020. P. 1-6. URL: https://dcenter.hse.ru/mirror/pubs/share/direct/373271455.pdf

23. Chernyavskiy A. Byudzhet. Otritsatel'nyy mayskiy balans [Negative May balance]. Byulleten " "KGB: Kommentarii o Gosudarstve i Biznese». №293, 2020, 22.06.2020. URL: https://dcenter.hse.ru/mirror/pubs/share/ direct/374630137.pdf

24. Ovcharova L., Gorina E. Developing Targeted Social Assistance in Russia: Impediments and Possibilities. Problems of Economic Transition. 2017. Vol. 59. No. 11-12. P. 843-864. 
25.Zubarevich N. Economic, Social, and Budget Problems of the Russian Regions in 2013-2016. The Journal of Comparative Economic Studies. 2017. No. 12. P. 53-78.

26.Zubarevich N. Regional and Local Government. Russia: Strategy, Policy and Administration. L.: Palgrave Macmillan, 2018. P. 367-380.

27.Zubarevich N. Regional Dimension of the New Russian Crisis. Social Sciences. 2015. Vol. 46. No. 4. P. 3-18.

28.Zubarevich N. Régions de Russie: sortie de crise et moteurs de croissance. Russie 2017: Regards de l'Observatoire franco-russe 2018. P.: Observo, 2018. P. 247-258.

29.Zubarevich N. The Relations Between the Center and the Regions. The State of Russia: What Comes Next? Houndmills: Palgrave Macmillan, 2015. P. 50-68.

30.Zubarevich N.V. Crises in post-Soviet Russia: Regional projection. Regional Research of Russia. 2016. Vol. 6. No. 2. P. 95-104.

31.Zubarevich N.V. Die Krise in den Regionen Russlands. Russland Analysen. 2016. No. 318. P. 2-8.

\section{ДАННЫЕ ОБ АВТОРЕ}

Кузина Наталья Владимировна, ведущий научный сотрудник, кандидат филологических наук, доцент Федеральное государственное бюджетное учреждение науки Центр исследования проблем безопасности РАН ул. Гарибальди, 21Б, г. Москва, 119335, Российская Федераџия nvkuzina@mail.ru

\section{DATA ABOUT THE AUTHOR}

Kuzina Natalia Vladimirovna, leading research worker, candidate of philological sciences, docent Center of research of problems of safety of the Russian academy of sciences 21b, Garibaldi Str., Moscow, 119335, Russian Federation nvkuzina@mail.ru

SPIN-code: 2069-8510

ORCID: 0000-0001-9094-7182

ResearcherID: AAF-2726-2019 